\title{
Osmotic responses of eggs and larvae of the Pacific herring to salinity and cadmium*
}

\author{
D. F. Alderdice ${ }^{1}$, T. R. RaO ${ }^{1} \&$ H. Rosenthal ${ }^{2}$ \\ ${ }^{1}$ Department of Fisheries and the Environment, Fisheries and Marine Service, \\ Pacific Biological Station; Nanaimo, British Columbia V 9 R 5 K 6, Canada, \\ and \\ ${ }^{2}$ Biologische Anstalt Helgoland (Zentrale); \\ Palmaille 9, D-2000 Hamburg 50, Federal Republic of Germany
}

\begin{abstract}
Pacific herring (Clupea pallasi) eggs fertilized in $20 \% \mathrm{~S}$ and incubated in 5, 20 or $35 \% \mathrm{~S}$ at $5{ }^{\circ} \mathrm{C}$, some being cross-transferred between 5 and $35 \% \mathrm{~S}, 61.8 \mathrm{hr}$ after fertilization, showed variable yolk and perivitelline fluid (PVF) osmolalities until beginning of epiboly. Coincident with blastopore closure and for a period of ca. $150 \mathrm{hr}$ thereafter (period of stability), both yolk and PVF osmoconcentrations were relatively constant. Thereafter osmolalities rose slowly to asymptotic levels prior to hatching. Osmolal values in the period of relative stability $(100-250 \mathrm{hr})$ were approximately (a) yolk: $285-310(5 \% \mathrm{~S}), 350(20 \% \mathrm{~S})$, and $390 \mathrm{mOsm}(35 \% \mathrm{~S})$; (b) perivitelline fluid: $105-118(5 \% \mathrm{~S}), 370(20 \% \mathrm{~S})$, and 530-670 $\mathrm{mOsm}(35 \% \mathrm{~S})$. Prior to hatching, these were (a) yolk: $330-350(5 \% \mathrm{~S}), 400(20 \% \mathrm{~S})$, and $460-480 \mathrm{mOsm}(35 \% \mathrm{~S})$; (b) perivitelline fluid: $175-210$ $(5 \% \mathrm{~S}), 530(20 \% \mathrm{~S})$, and $850-860 \mathrm{mOsm}(35 \% \mathrm{~S})$. Yolk osmolalities decreased, after hatching of the larvae, to approximate those levels attained between 100 and $250 \mathrm{hr}$. An hypothesis is presented whereby minimum osmotic work is defined on the basis of isosmotic relations existing between yolk, perivitelline fluid, and incubation medium. This leads to the description of a range of salinities defined in terms of osmoregulatory scope. At the $5^{\circ} \mathrm{C}$ test temperature, incubation salinities associated with maximum osmoregulatory scope (13.2-19\%) correspond closely to the range of salinities providing maximum or near-maximum hatches of viable larvae. The presence of a salinity-temperature interaction and its influence on the association between osmoregulatory scope and production of viable larvae is suggested as a mechanism underlying and providing the recognized plasticity of Pacific herring egg development. In a companion study involving cadmium as a contaminant, eggs incubated at $20 \% \mathrm{~S}$ were exposed to 0,1 or $10 \mathrm{ppm} \mathrm{Cd}$ in 5,20 or $35 \% \mathrm{~S}$ for 48 -hr periods at six stages of development between fertilization and hatching. Cd exposure resulted in a reduction in osmolality of perivitelline fluid. Reduction was greater in higher $\mathrm{Cd}$ concentrations and in eggs transferred to higher salinities. An hypothesis is presented to explain observed effects of $\mathrm{Cd}$ exposure on some physical properties of teleost eggs, including reductions in perivitelline fluid osmolality and egg volume. Finally, newly hatched $\left(0-, 3-, 6-\right.$ and 9 -day old) larvae from eggs incubated at $20 \% \mathrm{~S}\left(8.5^{\circ} \mathrm{C}\right)$ were exposed to salinities from 0 to $50 \%$ for a period of $72 \mathrm{hr}$. Median tolerance limits (72-hr) were 2.8-5.2\% for low salinities and 33-35.8\% for high salinities. No trends in salinity tolerance were noted amongst the four ages of larvae. The data suggest that natural larvae entrained in sea water would be susceptible to salinity-induced mortality in salinities greater than about $20 \%$. However, this conclusion is subject to confirmation in view of the low/low-high/high salinity-temperature interaction previously noted in relation to egg development, and its possible continuing influence in larval stages.
\end{abstract}

* Prepared under the auspices of the German-Canadian Scientific and Technical Cooperation Agreement (Contribution No. 18). 


\section{INTRODUCTION}

Throughout its geographic range, the Pacific herring (Clupea pallasi) spawns subtidally in coastal waters subject to wide fluctuations in salinity and temperature (Alderdice $8 x$ Velsen, 1971). In Japanese waters, spawning salinities of 17.43 to $18.47 \%$ have been recorded (Kurata 1959). In Russian waters, the Pacific herring has been observed to spawn in salinities of 15-35\% in the Sea of Japan, 14-33\% in the Sea of Okhotsk, 25-31\% in the Barents Sea, and 5-27\% in the White Sea (Dushkina, 1973). In Canadian waters, McMynn \& Hoar (1953) noted spawnings in association with salinities of 8.21 to $27.68 \%$. In a recent series of observations (D. Outram, personal communication); salinities on or adjacent to spawning grounds in the spawning period ranged from 2.6 to $28.7 \%$ in Georgia Strait, southern British Columbia. However the modal frequency occurred at salinities of $27-28.7 \%$ (and $8.0-8.9^{\circ} \mathrm{C}$ ), and three-quarters of the observations occurred at salinities of $24-28.7 \%$ (and $7.0-9.9{ }^{\circ} \mathrm{C}$ ).

In comparison, Atlantic herring (C. harengus) are reported to spawn in salinities of 5 to $35 \%$ (Holliday \& Blaxter, 1960; Blaxter \& Holliday, 1963). The range of spawning salinities of the two species tend to be quite similar. Both appear to be euryhaline and capable of spawning over a wide range of salinities. Some of this apparent plasticity may be indicative of the presence of physiological races; Alderdice \& Velsen (1971) noted that Pacific herring eggs from ichthyoplankton samples in Russian waters were found at temperatures lethal to British Columbia herring eggs. These authors also noted the presence of a low/low-high/high interaction between salinity and temperature whereby egg development and survival are maximized at low temperatures in low salinities, and at higher temperatures in higher salinities.

Salinity tolerance of eggs and larvae of Atlantic herring has been more thoroughly documented (Holliday \& Blaxter, 1960; Blaxter \& Holliday, 1963; Holliday, 1965, 1969; Holliday \& Jones, 1965). In laboratory studies of Atlantic herring, fertilization, development, and hatching occur in salinities from 5.9 to $52.5 \%$ (Holliday \& Blaxter, 1960). Maximum fertilization rates occur at salinities of $25 \%$ and greater, percentage hatch is maximized at salinities near $25 \%(20-35 \%$, and the larvae are tolerant of salinities between 2.5 and $52.5 \%$ (168-hr exposure period). However, yolksac larvae appear to survive longer in salinities between 10 and $20 \%$, while tolerance both to high and low salinities tends to decrease in older larvae (Holliday, 1965).

Laboratory studies suggest that eggs and larvae of Pacific herring are somewhat less tolerant of high salinities. Fertilization rates $>$ than $50 \%$ occur at salinities between approximately 4.5 and $42 \%$; such rates are maximized at salinities between 12 and $15 \%$ (Alderdice \& Velsen, 1978). Ultimate maximum (optimum) hatch of viable larvae is calculated to occur at a temperature of $8.3^{\circ} \mathrm{C}$ and a salinity near $16.98 \%$, within a plausible range of 13 to $19 \% \mathrm{~S}$ (Alderdice \& Velsen, 1971). McMynn \& Hoar (1953) concluded that salinity tolerance of Pacific herring eggs was high between 5 and $25 \% \mathrm{~S}$ (their Fig. 9), and was maximal between 11.5 and $16.2 \% \mathrm{~S}$. Their larvae, in general, tolerated salinities of 6.1 to $34.3 \%$ over a 6 -day period following hatching. Other estimates of larval tolerance show maxima near $22.6 \%$ (Kurata, 1959), and $25.8 \%$ (Fujita \& Kokubo, 1927). Alderdice \& Velsen (1971) noted that longest survival of larvae on their yolk stores occurred at salinities of 16.4-25.0\%. 
We suspect that Pacific herring in British Columbia waters probably spawn most frequently in waters of intermediate salinity (24-28.7\%), within a total range of 8-28\% S (Alderdice \& Velsen, 1971). It has been suggested (Stevenson, 1962) that one principal cause of mortality among Pacific herring larvae may be their passive transport by currents to the open sea, where higher salinities may limit survival.

This report considers the question of salinity tolerance among Pacific herring eggs and larvae by examination of (1) osmotic properties of the perivitelline fluid and yolk of eggs incubated in a range of salinities, and (2) salinity tolerance of larvae in the 10-day period following hatching. When these investigations were undertaken, a parallel objective sought to survey the effects of exposure of incubating eggs to cadmium. Therefore, (3) additional data are presented on the effect of cadmium exposure during incubation on the osmotic properties of developing eggs.

\section{MATERIALS AND METHODS}

Ripe Pacific herring were obtained from a trapnet at Long Harbour, Georgia Strait $\left(48^{\circ} 51^{\prime} \mathrm{N}\right.$ lat $123^{\circ} 27^{\prime} \mathrm{W}$ long) on March 8-9, 1974 as described in related studies reported elsewhere (Alderdice et al., 1979a, b). Briefly, the adults were transported in chilled, oxygenated sea water to the Nanaimo laboratory where they were maintained in large, circular tanks of flowing sea water $(28 \pm 1 / 2 \% \mathrm{~S})$ at $8-9{ }^{\circ} \mathrm{C}$. These fish, initially fed frozen marine plankton, were weaned onto a diet of commercial salmon pellet feed within 10 days, and were maintained in spawning condition for a period of about $2 \frac{1}{2}$ months.

\section{Osmotic properties of eggs}

Eggs were expressed in a single layer onto clean glass microcoverslips $(0.2 \times 22 \mathrm{~mm}$ diam), 20-25 eggs per coverslip. Strong adhesion of the eggs to the glass surface facilitated extraction of egg fluids in subsequent measurements of osmoconcentration. The coverslips and adhering, unfertilized eggs were arranged vertically in the grooves of special Plexiglas racks. Five racks of 30 coverslips were prepared and stored in water of $20 \% \mathrm{~S}$ at $4{ }^{\circ} \mathrm{C}$ until sample preparation was complete $(1 \mathrm{hr})$. All eggs then were fertilized simultaneously in $20 \% \mathrm{~S}$ sea water at $4{ }^{\circ} \mathrm{C}$ over a 10 -min period. The racks of samples were rinsed $(20 \% \mathrm{~S}$, $4{ }^{\circ} \mathrm{C}$ ) and transferred to the incubation salinities in $40-1$ tanks at $5.0 \pm 0.1^{\circ} \mathrm{C}$. Half the volume of water in each tank was exchanged every 4 days to minimize bacterial and protozoan contamination. Salinities lower than that of the seawater supply (ca. $28 \% \mathrm{~S}$ ) were obtained by dilution with fresh water; higher salinities were obtained by addition of synthetic sea salt (Rila Marine Mix, Rila Products, Teaneck, N. J.) to sea water. The tanks were aerated continually to provide for water circulation and oxygenation of the eggs.

Five sets of incubations were employed (Table 1). After fertilization (20\% S), Series $\mathrm{A}$ and $\mathrm{B}$ were moved to $5 \% \mathrm{~S}$, Series $\mathrm{C}$ to $20 \% \mathrm{~S}$, and D and $\mathrm{E}$ to $35 \% \mathrm{~S}$. At the late gastrula stage and beginning of epiboly $(61.8 \mathrm{hr})$, Series $\mathrm{B}$ was transferred from 5 to $35 \% \mathrm{~S}$, and Series D from 35 to $5 \% \mathrm{~S}$. The remaining series (A, C, E) remained in their original incubation media of 5,20 and $35 \% \mathrm{~S}$, respectively. 
Table 1

Incubation conditions employed in the osmoconcentration series. Pacific herring eggs were fertilized $(0 \mathrm{hr})$ in $20 \% \mathrm{~S}$ sea water, moved to incubation salinities of 5,20 or $35 \%, 10 \mathrm{~min}$ after fertilization, and subsamples were cross-transferred among the incubation salinities $61.8 \mathrm{hr}$ after fertilization

\begin{tabular}{|c|c|c|c|c|}
\hline $\begin{array}{c}\text { Temperature }\left({ }^{\circ} \mathrm{C}\right) \\
\text { Time (hr) }\end{array}$ & $\begin{array}{l}4 \\
0\end{array}$ & & $\begin{array}{c}5 \\
0.16\end{array}$ & $\begin{array}{c}5 \\
61.8\end{array}$ \\
\hline $\begin{array}{c}\text { Series } \\
\text { A } \\
\text { B } \\
\text { C } \\
\text { D } \\
\text { E }\end{array}$ & $\begin{array}{l}20 \\
20 \\
20 \\
20 \\
20\end{array}$ & $\begin{array}{l}\rightarrow \\
\rightarrow \\
\rightarrow \\
\rightarrow\end{array}$ & $\begin{array}{r}5 \\
5 \\
20 \\
35 \\
35\end{array}$ & $\begin{array}{r}5 \\
5 \\
20 \\
35 \\
35\end{array}$ \\
\hline
\end{tabular}

Sampling of egg fluids in all test salinities began 10-20 min after ferilization, and thereafter was maintained at 24-hr intervals until the eggs hatched. Osmoconcentration of the perivitelline fluid (PVF) and yolk was measured at each sampling time, except in the initial 10-min samples where the perivitelline fluid was just beginning to form.

Sampling consisted of moving a coverslip from the appropriate tank to a petri dish of sea water of the same salinity at $5{ }^{\circ} \mathrm{C}$. The number of unfertilized eggs in the total and the stage of development were recorded. The adhering eggs were rinsed for 1-2 sec in double distilled water. Water adhering to the eggs was removed by exposure of the eggs for a few seconds to a gentle air stream from a capilliary tube. The coverslip was transferred immediately to a prepared well slide $(5 \times 23 \mathrm{~mm}$ diam) where it was submerged in light Cargille oil (Type A).

Egg fluids were obtained under the oil to eliminate evaporation of sample fluid. Samples were taken using disposable micropipettes drawn from non-heparinized microhaematocrit capillary tubes. The micropipettes were coated internally with a $1 \%$ solution of Siliclad (Clay-Adams) to eliminate surface tension, and dried before use. Under a binocular microscope the egg capsule was pierced with an iris scalpel and fluid samples averaging 3.2-3.4 $\mathrm{nl}$ were withdrawn between plugs of Cargille oil from the well slide by means of a mouth suction tube. For every PVF or yolk sample a new micropipette was used, and samples were rejected if cross-contamination was suspected. After a PVF sample had been obtained, the remaining perivitelline fluid was expressed gently through the ruptured capsule, allowing the surrounding oil to flow in and surround the yolk. This procedure virtually eliminated the possibility of cross-contamination of samples. At the end of the incubation period, yolk samples also were obtained from newly hatched larvae.

Osmoconcentration of PVF and yolk samples was measured using a nannoliter osmometer (Clifton Technical Physics, Hartford, N. Y.). Use of the instrument is well described by Frick \& Sauer (1973). Basically, the technique depends on the principle that a l-molal ( $1 \mathrm{~g}$-mol solute/ $\mathrm{kg}$ solvent) solution of an ideal non-electrolyte in water has a freezing point depression $(\triangle)$ of $1.858^{\circ} \mathrm{C}$. Then the osmolal concentration of a solution, whose $\triangle=1.858^{\circ} \mathrm{C}$, is 1 osmole $/ \mathrm{kg}(\mathrm{Osm} / \mathrm{kg})$ or 1000 milliosmoles $/ \mathrm{kg}(\mathrm{mOsm} / \mathrm{kg})^{*}$ (Potts \& Parry, 1964).

* Henceforth the term mOsm will be used, it being understood that osmolality is measured as $\mathrm{mOsm} / \mathrm{kg}$. 
The osmometer was calibrated initially, and checked periodically thereafter, using deionized water $(0 \mathrm{mOsm})$ and standard $\mathrm{NaCl}$ solutions. The latter were prepared using the tabled relation between $\triangle$ and molarity (Washburn, 1928). Converting to molality:

Molality $(\mathrm{g}-\mathrm{mol} / \mathrm{kg})=1000\left(\mathrm{M}_{\mathrm{v}} / \mathrm{C}_{\mathrm{w}}\right)$

where $\mathrm{M}_{\mathrm{v}}=$ molarity $(\mathrm{g}-\mathrm{mol} / \mathrm{l})$ and $\mathrm{C}_{\mathrm{w}}=\operatorname{total}$ water $(\mathrm{g} / \mathrm{l})$

(Weast, 1969). The relation between the logarithms of $\mathrm{NaCl}$ solution molality and $\triangle$ is linear, leading to the calculated defining relation

$$
\log \triangle=0.5268+0.9863 \log \mathrm{M}_{\mathrm{w}}
$$

where $\mathrm{M}_{\mathrm{w}}=$ molality ( $\mathrm{g}-\mathrm{mol} / \mathrm{kg}$ ). With this relationship, the instrument was calibrated so that its scale reproduced the theoretical freezing point depression of standard $\mathrm{NaCl}$ solutions of known molality. The osmolality of egg fluids and test salinities then was obtained from the relation Osm $=\triangle 1$.858, $\triangle$ being determined experimentally. As a further convenience, the relation between osmolality and salinity was determined experimentally:

$\mathrm{mOsm}=30.8094 \mathrm{~S}(\%)$

In practice, each unknown sample was analyzed concurrently with samples of two standards (usually 0 and 807 or $1075 \mathrm{mOsm}$ ) that bridged the presumed value of the unknown. Minor deviations from expected values of $\triangle$ occurred in these "working standards", resulting from temperature-related subtle fluctuations in performance of the instrument. The determined value of an unknown then was adjusted with reference to the working standard scale and back-corrected to its equivalent on the calibration scale. Such corrections usually were in the order of 2-3 mOsm.

\section{Influence of cadmium on osmoconcentration}

Eggs from the same source as those in the previous series were prepared as outlined earlier. However, the eggs were applied to glass microscope slides, fertilized in $20 \% \mathrm{~S}$ sea water $\left(4^{\circ} \mathrm{C}\right)$ as before, then moved to incubation salinities of 5,20 , and $35 \%$

Table 2

Clupea pallasi embryos. Transfer time to cadmium-contaminated media and development stages observed

\begin{tabular}{|c|c|c|c|}
\hline $\begin{array}{l}\text { Embryonic } \\
\text { stage }\end{array}$ & $\begin{array}{c}\text { Interval } \\
(\mathrm{hr})\end{array}$ & $\begin{array}{l}\text { Designation and time observed } \\
\text { (hr) }\end{array}$ & $\begin{array}{l}\text { Transfer time to } \\
\text { Cd series (hr) }\end{array}$ \\
\hline 1 & $0-20$ & $\begin{array}{l}\text { fertilization }(0) \text { to early } \\
\text { blastodermal cap }(20)\end{array}$ & $30-32$ \\
\hline 2 & $20-100$ & $\begin{array}{l}\text { germ ring at equator of } \\
\text { yolk }(65)\end{array}$ & $57-59$ \\
\hline 3 & $100-240$ & $\begin{array}{l}\text { blastopore closure }(105-135) \\
\text { to embryo encircling yolk } \\
\text { once }(205-240)\end{array}$ & $127-130$ \\
\hline 4 & $240-340$ & $\begin{array}{l}\text { to beginning of eye } \\
\text { pigmentation }(320-345)\end{array}$ & $247-250$ \\
\hline 5 & $340-450$ & $\begin{array}{l}\text { to embryo encircling yolk } \\
\text { twice }(400-425)\end{array}$ & $343-345$ \\
\hline 6 & $450-700$ & to hatching $(570-755)$ & $486-496$ \\
\hline
\end{tabular}


between 30 and 32 min after fertilization. In contrast with the previous series, the eggs in this series were moved to the incubation tanks at a time when about $20 \%$ of perivitelline fluid formation would have occurred. Consequently, the response of the eggs in these two series may differ because of differences in salinity experience during formation of the perivitelline fluid.

Later, subsamples of eggs were transferred from each initial salinity to 5, 20, or $35 \% \mathrm{~S}$ sea water containing either 0,1 or $10 \mathrm{ppm}$ of cadmium prepared from the anhydrous chloride salt. These final transfers were made at six development stages spaced throughout the incubation period. These stages, their designations, and the corresponding times of transfer (hours after fertilization) are shown in Table 2.

At each of the six transfer times, changes in osmoconcentrations of the perivitelline fluid were followed for a period of $48 \mathrm{hr}$ in relation to salinity change and cadmium concentration. In addition, yolk samples were obtained from a small number of the transferred eggs.

\section{Salinity tolerance of larvae}

Larvae were obtained from eggs fertilized in $14.12 \% \mathrm{~S}$ sea water at $5{ }^{\circ} \mathrm{C}$, a salinity in the range providing maximum rate of fertilization for Pacific herring eggs (Alderdice $\&$ Velsen, 1978). The eggs then were transferred to $20 \% \mathrm{~S}$ sea water $\left(5^{\circ} \mathrm{C}\right) ; 398.5 \mathrm{hr}$ after fertilization the temperature was raised from 5 to $8.5^{\circ} \mathrm{C}$ in increments of $1{ }^{\circ} \mathrm{C} / \mathrm{day}$, and the larvae hatched at $20 \% \mathrm{~S}, 8.5^{\circ} \mathrm{C}$. This incubation regime was used to provide a maximum number of viable larvae in the period available for the trials. Larvae hatching only at the peak of the hatching period were used; they were held at $20 \% \mathrm{~S}$ and $8.5^{\circ} \mathrm{C}$ until needed. Using these larvae, preliminary tolerance tests were undertaken at $20 \% \mathrm{~S}, 8.5{ }^{\circ} \mathrm{C}$, with the following results (Table 3 ).

Based on these trials, salinities below $5 \%(0,2.5,3.75,5)$ and above $27 \%(27,31,35$, $40,50)$ were chosen to establish estimates of the upper and lower salinity tolerance thresholds. Larvae in $20 \% \mathrm{~S}$ sea water acted as controls. Salinities $( \pm 0.2 \%)$ were prepared as described earlier. All trials were conducted at $8.5\left( \pm 0.1^{\circ} \mathrm{C}\right)$, a temperature

Table 3

Salinity tolerance and corresponding yolk osmolalities in newly hatched herring larvae

\begin{tabular}{|c|c|c|c|c|c|c|c|}
\hline $\begin{array}{c}\text { Salinity } \\
(\% \circ)\end{array}$ & 0 & $\begin{array}{c}\text { Average } \\
0.25\end{array}$ & $\begin{array}{c}\text { osmol } \\
0.3 \\
(\mathrm{hr}) \\
\end{array}$ & $\begin{array}{r}(\mathrm{mO} \\
0.75\end{array}$ & 3.0 & $\begin{array}{c}\text { Mortality } \\
\text { at } 3 \mathrm{hr} \\
(\%)\end{array}$ & $\begin{array}{c}\text { Estimated } \\
\mathrm{ET}_{50} ; *: 6 \\
(\mathrm{hr})\end{array}$ \\
\hline 0 & - & 309.0 & - & 303.0 & - & 100 & 0.9 \\
\hline 5 & - & - & - & - & 297.0 & - & - \\
\hline 20 & $345.4 *$ & - & - & - & 334.5 & 0 & $>72$ \\
\hline 35 & - & - & - & - & 474.7 & 38.7 & 35 \\
\hline 50 & - & - & 415.1 & - & 613.7 & 93.3 & 8 \\
\hline
\end{tabular}


within the range normally found during the spawning and hatching period of herring in British Columbia waters $\left(8.5-10^{\circ} \mathrm{C}\right)$ (Alderdice \& Velsen, 1971).

Trials were conducted in covered 350-ml crystallizing dishes using two replicates of 15 larvae in each test salinity. Each series of tests lasted $72 \mathrm{hr}$ and four series were undertaken, using 0-, 3-, 6-, and 9-day old larvae. The larvae were unfed before and during the tests. Water in the containers was acrated to saturation twice daily and fresh medium was used in each of the four series. In situ microscopic examination of the larvae at intervals determined the number of dead or moribund larvae in each test. Moribund larvae were judged nonviable; in spite of continued cardiac function these larvae showed prominent opacity of the brain and anterior spinal cord, and usually were inactive. For each of the four series, cumulative distributions of mortality were drawn on probit-log time scales to obtain graphic estimates of the effective time to $50 \%$ mortality $\left(\mathrm{ET}_{50}\right)$ for each salinity in each series. In addition, mortality at the end of the test period provided estimates of the upper and lower salinity tolerance levels $\left(72-\mathrm{hr}_{\mathrm{TL}} \mathrm{TL}_{\mathrm{m}}\right)$.

\section{RESULTS}

\section{Osmotic properties of eggs}

Some sources of variability were examined for the measured yolk and PVF osmolalities in the $20 \% \mathrm{~S}$ incubation series. As described earlier, each experimental determination was interpolated between working standards measured at the same time, and then corrected with reference to the calibration scale. The differences between the raw data and the corrected data averaged $\pm 2.3 \mathrm{mOsm}$ for the perivitelline fluid, and $\pm 4.2 \mathrm{mOsm}$ for the yolk. In addition, variation within samples, based on replicate samples from each of two eggs, averaged $\pm 5.1 \%$ around the PVF means, and $\pm 3.4 \%$ around the yolk sample means.

Osmolal properties of the perivitelline fluid and yolk in the five incubation series (Table 1) are shown in Fig. $1(\mathrm{a}, \mathrm{b}, \mathrm{c}$ ). In the figure, logarithms of milliosmole values have been used; by inspection, the transformation tends to stabilize the variances. Three aspects of the time series in the figure deserve mention: (a) changes in osmoconcentration with time in relation to embryonic development, (b) variations in the trends of osmoconcentration in relation to incubation salinity, and (c) the interrelation of perivitelline fluid and yolk osmolality within each series. These may be summarized as follows.

Trends of change of osmoconcentration (Fig. 1) are shown in a simplified interpretation in Fig. 2. There, average osmolal values are given at the midpoints of the intervals of the six embryonic stages described earlier. The trends suggest that osmolal values become relatively stable between 100 and $250 \mathrm{hr}$ after fertilization. Following this period of relative stability there is a rise between 200 and $400 \mathrm{hr}$ to asymptotic levels of osmolality prior to hatching. These trends were present in all series.

Variations in osmoconcentration in relation to incubation salinity are of two types those occurring before and those after approximately $100 \mathrm{hr}$ of incubation. Prior to $100 \mathrm{hr}$, yolk osmolality approximates that in the following period of relative stability among eggs exposed initially to 20 and $35 \% \mathrm{~S}$. For eggs exposed to $5 \% \mathrm{~S}$, there is an early and 

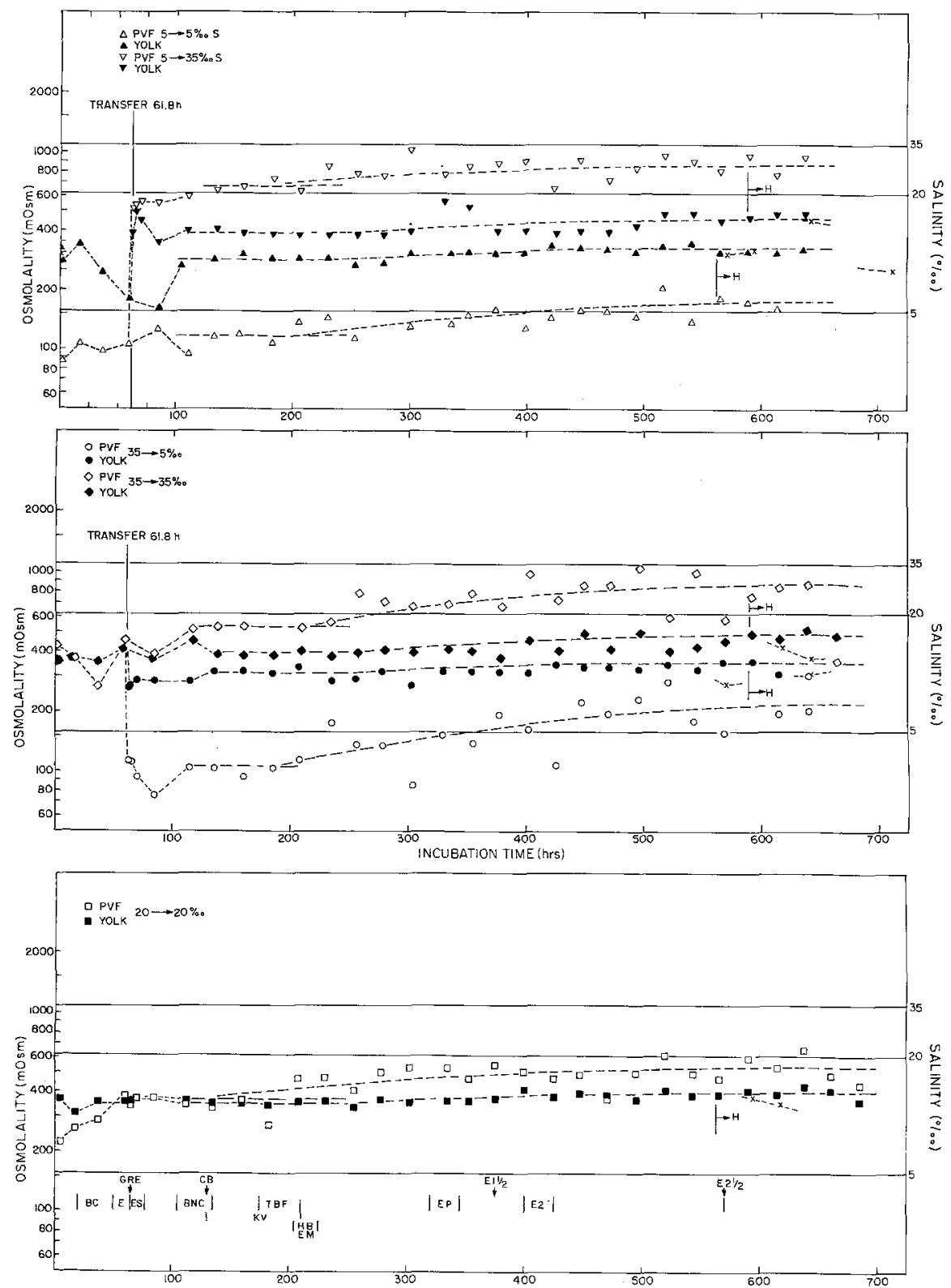

Fig. 1: Yolk and perivitelline fluid osmolality of Pacific herring eggs fertilized in $20 \% \mathrm{~S}\left(5^{\circ} \mathrm{C}\right)$ and moved 10 min after fertilization to (a) $5 \%$, (b) $20 \%$ and (c) $35 \%$ S for incubation. Subsamples of eggs were cross-transferred between incubation salinities of 5 and $35 \%, 61.8 \mathrm{hr}$ after fertilization (panels $a, c)$. In panel b, observed developmental stages are indicated: BC - blastodermal cap, E epiboly, GRE - germ ring at equator of yolk. ES - embryonic shield, BNC - blastopore near closure, $\mathrm{CB}$ - closure of blastopore, $\mathrm{KV}$ - Kupffer's vesicle present, $\mathrm{TBF}$ - tail bud free from yolk surface, $\mathrm{HB}$ - heart beating, EM - embryonic movement starting, EP - eye pigmentation, E 1 1 1/2, 2, 2 1/2 - embryo encircling yolk $1 \frac{1}{2}, 2,21 / 2$ times, $\mathrm{H}$ - hatching 


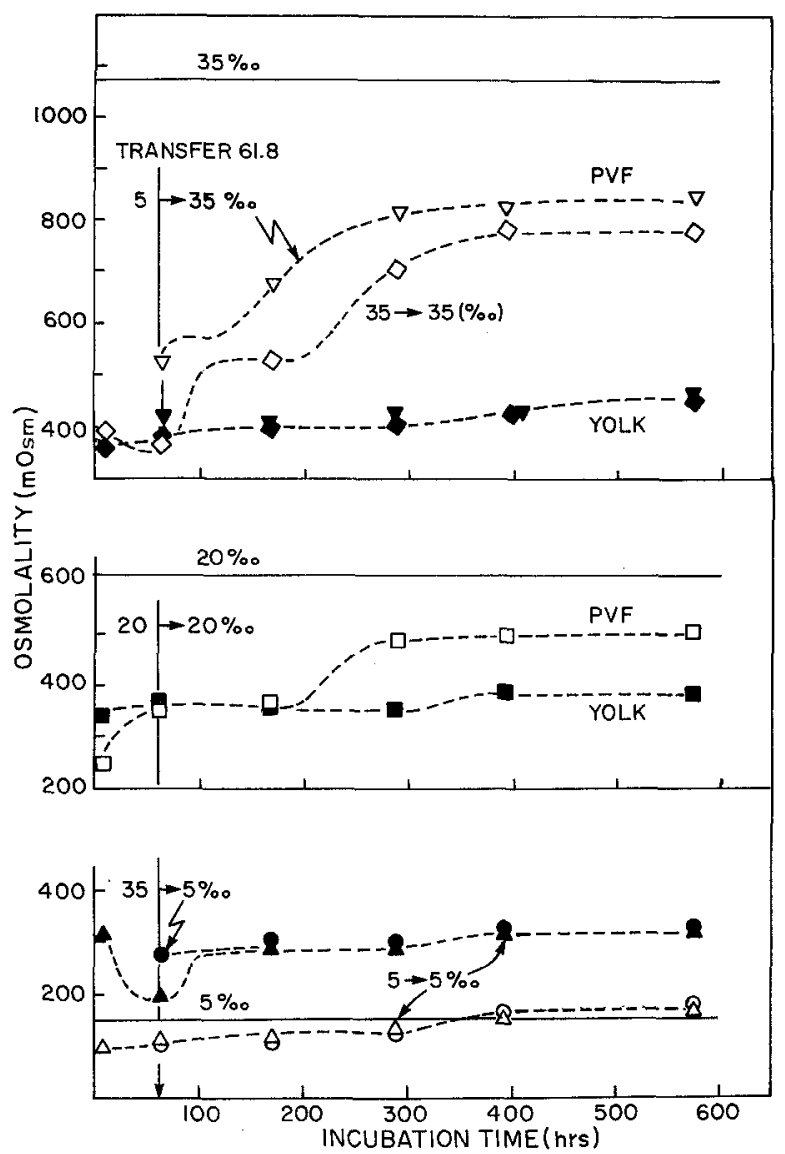

Fig. 2. Simplifed interpretation of osmoconcentration trends in yolk and perivitelline fluid of Fig. 1 based on average osmolalities within the intervals associated with six developmental stages between fertilization and hatching (see text). For symbols see Figure 1

substantial decrease in yolk osmolality; about $85 \mathrm{hr}$ after fertilization the level increased to that achieved in the period of relative stability (100-250 hr). Prior to $100 \mathrm{hr}$, yolk osmolality appears to have been influenced by early salinity experience. Following crosstransfer of eggs between salinities $(61.8 \mathrm{hr})$, yolk osmolalities appear to be regulated in relation to the final incubation salinity, irrespective of the salinity to which they were exposed prior to transfer (Fig. 2). Osmolality of the perivitelline fluid is subject to greater changes than the yolk, although in most instances the trends are similar after $100 \mathrm{hr}$. From 100 to beyond $200 \mathrm{hr}$, PVF osmolality is fairly uniform; as for the yolk, the level of osmoconcentration achieved is increased at the higher incubation salinities. Following this period of relative stability there is a further rise to rather stable levels near hatching. The rise is minimal ( $\sim 50 \mathrm{mOsm}$ ) for eggs incubated in or transferred to $5 \% \mathrm{~S}$ (Fig. 2). The rise is more evident ( $\sim 150 \mathrm{mOsm}$ ) among eggs incubated at $20 \% \mathrm{~S}$, and is still higher $(\sim 250 \mathrm{mOsm})$ for eggs incubated in or transferred to $35 \% \mathrm{~S}$. In the latter, osmolality of 


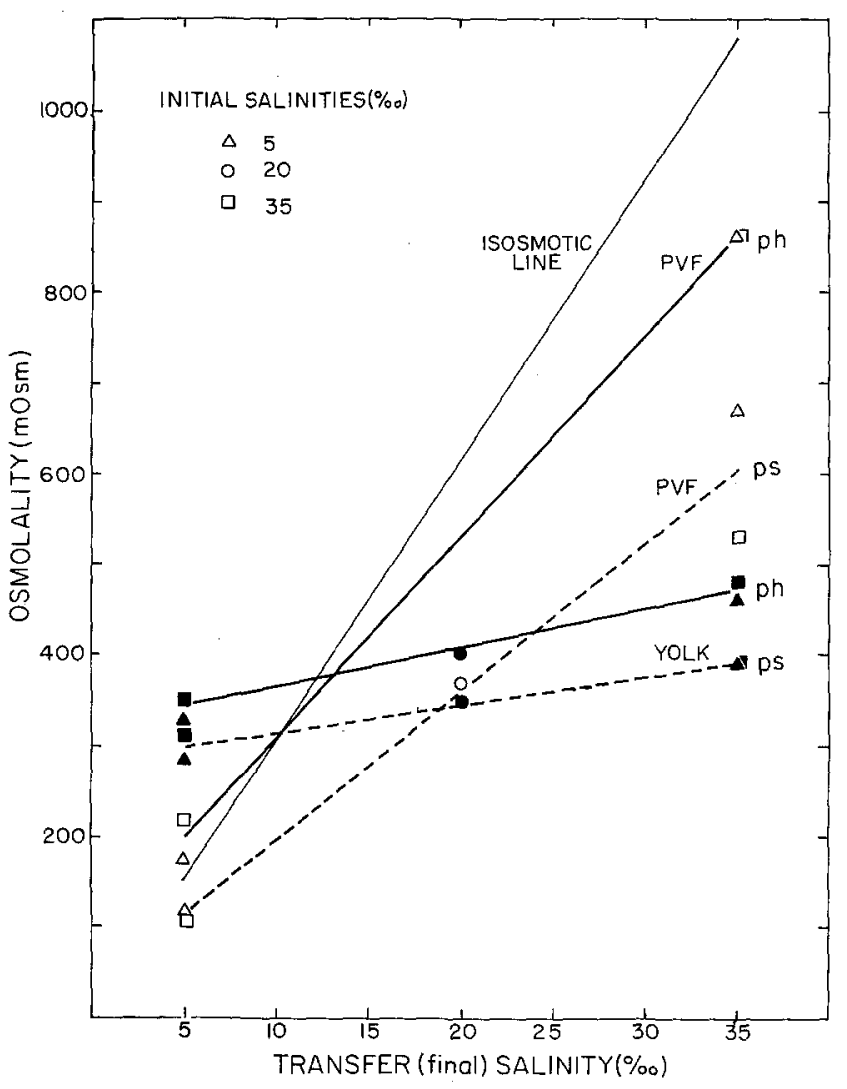

Fig. 3: Yolk and perivitelline fluid (PVF) osmolatities in the period of stability (ps) 100-250 hr after fertilization, and just prior to hatching (ph) in relation to "final" incubation salinities. Some subsamples of eggs were crosstransfered (61.8 hr after fertilization) between 5 and $35 \% \mathrm{~S}$. Initial salinities are identified in the body of the figure. Open symbols: perivitelline fluid; closed symbols: yolk. Isosmotic line: osmolality (mOsm) $\equiv$ salinity $(\%)$

the perivitelline fluid following transfer of eggs from 5 to $35 \% \mathrm{~S}$ reaches a higher final value compared with eggs remaining in $35 \% \mathrm{~S}$ without transfer. These data suggest that the response to high salinity later in the incubation period may be affected by early, low salinity experience. The distributions of osmolality illustrated in Fig. 1 and interpreted in Fig. 2 lead to the proposition that the influence of the five incubation regimes be compared in the two periods when osmoconcentration is relatively stable - after blastopore closure (100-250 hr) and prior to hatching (Table 4). The relations between PVF and yolk osmolality and final incubation salinities - in constant salinities or after transfer at $61.8 \mathrm{hr}-$ are illustrated for the two periods in Fig. 3.

Just prior to the beginning of hatching, approximately 100 eggs from each incubation series were segregated to estimate egg survival. The results (Table 5) were tabulated when hatching was complete. In addition, a small number of yolk samples were obtained from newly hatched larvae (Table 6). In most instances there was a decrease in yolk osmolality 
Table 4

Osmolality (mOsm) of the yolk and perivitelline fluid (PVF) of Pacific herring eggs: (a) in the period of stability (100-250 hr), (b) final prehatching levels. The estimates are from the graphs in Fig. 1

\begin{tabular}{|ccccc|}
\hline $\begin{array}{c}\text { Incubation } \\
\text { salinity } \\
(\%)\end{array}$ & \multicolumn{2}{c}{ Period of stability } & \multicolumn{2}{c|}{ Prehatching } \\
\hline $5 \rightarrow 5$ & yolk & PVF & yolk & PVF \\
$5 \rightarrow 35$ & 285 & 117 & 330 & 175 \\
$20 \rightarrow 20$ & 390 & 670 & 460 & 860 \\
$35 \rightarrow 5$ & 350 & 370 & 400 & 530 \\
$35 \rightarrow 35$ & 310 & 105 & 350 & 220 \\
$*$ mOsm equivalents: $5 \%$ & 390 & 530 & 480 & 860 \\
\end{tabular}

Table 5

Mortality estimates in samples of eggs from the five incubation conditions after completion of hatching

\begin{tabular}{|cccccc|}
\hline Series & $\begin{array}{c}\text { Salinity } \\
(\% 0)\end{array}$ & $\begin{array}{c}\text { Eggs } \\
(\mathrm{N})\end{array}$ & $\begin{array}{c}\text { Total hatch } \\
(\%)\end{array}$ & $\begin{array}{c}\text { Normal hatch } \\
(\%)\end{array}$ & $\begin{array}{c}\text { Dead eggs } \\
(\%)\end{array}$ \\
\hline A & $(5 \rightarrow 5)$ & 102 & 89.2 & 78.4 & 10.8 \\
B & $(5 \rightarrow 35)$ & 57 & 35.1 & 22.8 & 64.9 \\
C & $(20 \rightarrow 20)$ & 76 & 89.5 & 75.0 & 10.5 \\
E & $(35 \rightarrow 5)$ & 95 & 93.7 & 78.9 & 6.3 \\
& $(35 \rightarrow 35)$ & 71 & 76.1 & 49.3 & 23.9 \\
\hline
\end{tabular}

Table 6

Estimates of yolk osmoconcentration in newly hatched larvae

\begin{tabular}{|ccccc|}
\hline Series & $\begin{array}{c}\text { Salinity } \\
(\% \circ)\end{array}$ & $\begin{array}{c}\text { Time after fertilization } \\
(\mathrm{hr})\end{array}$ & $\begin{array}{c}\text { Osmolality } \\
(\mathrm{mOsm})\end{array}$ & $\begin{array}{c}\text { Average } \\
(\mathrm{mOsm})\end{array}$ \\
\hline $\mathrm{A}$ & $(5 \rightarrow 5)$ & 571 & 305 & \\
& & 594 & 325 & 294 \\
$\mathrm{~B}$ & $(5 \rightarrow 35)$ & 712 & 253 & 452 \\
$\mathrm{C}$ & $(20 \rightarrow 20)$ & 642 & 452 & 358 \\
& & 594 & 376 & \\
$\mathrm{D}$ & $(35 \rightarrow 5)$ & 617 & 340 & \\
& & 571 & 272 & \\
$\mathrm{E}$ & $(35 \rightarrow 35)$ & 641 & 305 & 393 \\
& & 618 & 361 & 369 \\
\hline
\end{tabular}

after hatching, and the levels of osmoconcentration attained approximate those found in the eggs in the earlier period of relative stability (100-250 $\mathrm{hr}$ after fertilization). 


\section{Influence of cadmium on osmoconcentration}

Typical changes in osmoconcentration of the perivitelline fluid in the 48-hr periods following transfer of eggs (to 0,1 , or $10 \mathrm{ppm} \mathrm{Cd}$ ) are illustrated in Fig. 4 for the six developmental stages considered. Noted from the figure is the fact that marked changes in PVF osmolality occurred in the 48-hr period following transfer; the evidence indicates that in almost all instances the perivitelline fluid had not attained equilibrium in its new environment in the 48 -hr period following transfer. However, similar variability in osmolality of the control eggs ( 0 ppm Cd) also was noted, even where no salinity change occurred (e. g. $20 \rightarrow 20 \% \mathrm{~S}$ ). The variations in all instances are greater than might be attributed to random error. We conclude from the available data that rapid changes in PVF osmolality may occur over short intervals, particularly within the first $100 \mathrm{hr}$ of incuba-

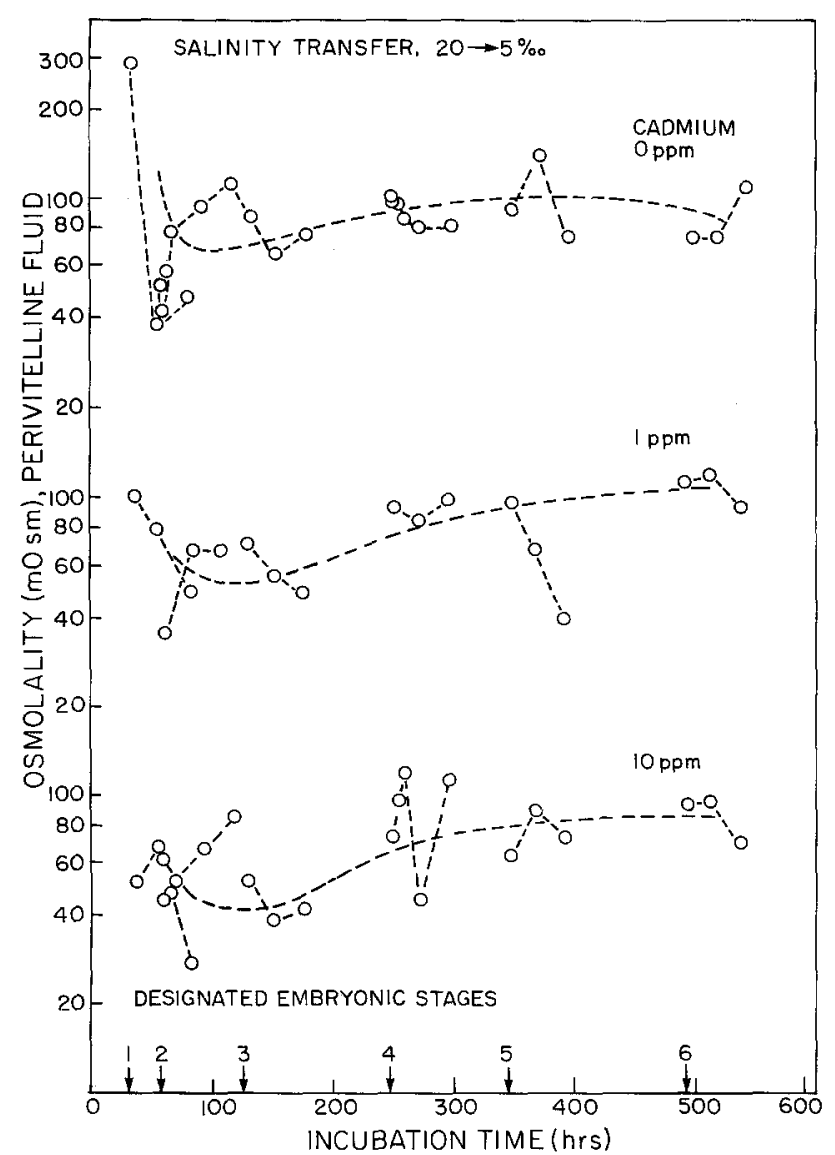

Fig. 4: Pervitelline fluid osmolality of Pacific herring eggs incubation at $20 \% \mathrm{~S}\left(5^{\circ} \mathrm{C}\right)(0 \mathrm{ppm} \mathrm{Cd})$ and moved at six developmental stages to $5 \% \mathrm{~S}$ and 0,1 , or $10 \mathrm{ppm} \mathrm{Cd}$. The clusters of points identify osmolal readings in the 48 -hr periods following transfer. For the designated embryonic stages $(1-6)$, see text. Trend lines are drawn through the means of each cluster of points. The three distributions in the figure are examples from Table 7 
tion; these variations occurred whether the external salinity was constant or not, and either in the presence or absence of cadmium. Owing to this variability, the data were averaged for each of the six developmental stages at which egg transfer occurred. The trends obtained (Fig. 4) are representative of most of the trials. There is a tendency for PVF osmolality to decline in the first $100 \mathrm{hr}$ of incubation, reach a minimum around 100 to $200 \mathrm{hr}$, then rise to an asymptotic level prior to hatching. The minima attained between 100 and $200 \mathrm{hr}$ also tend to be at lower osmolal levels in higher cadmium concentrations.

Based on these observations, the average PVF osmolalities at each developmental stage are compared for all salinity transfers and all cadmium concentrations (Table 7). Examination of the table shows that the overall average PVF osmolalities (final column, Table 7) are lower, in general, than those obtained for stage 6 (e. g. compare initial salinities of $20 \% \mathrm{~S}$; 0,1 and $10 \mathrm{ppm} \mathrm{Cd}$ ). We assume the overall averages mask possible trends in the relationships. That is, they overestimate the lower osmolalities occurring in the 100-200 hr period, and underestimate the asymptotic trends toward the end of the incubation period. Within these constraints the averages provide a method of comparing the data. It is evident that PVF osmolality is depressed in the presence of cadmium (Fig. 5a), and that depression of osmolality is intensified in eggs maintained in or transferred to higher salinities (Fig. 5b).
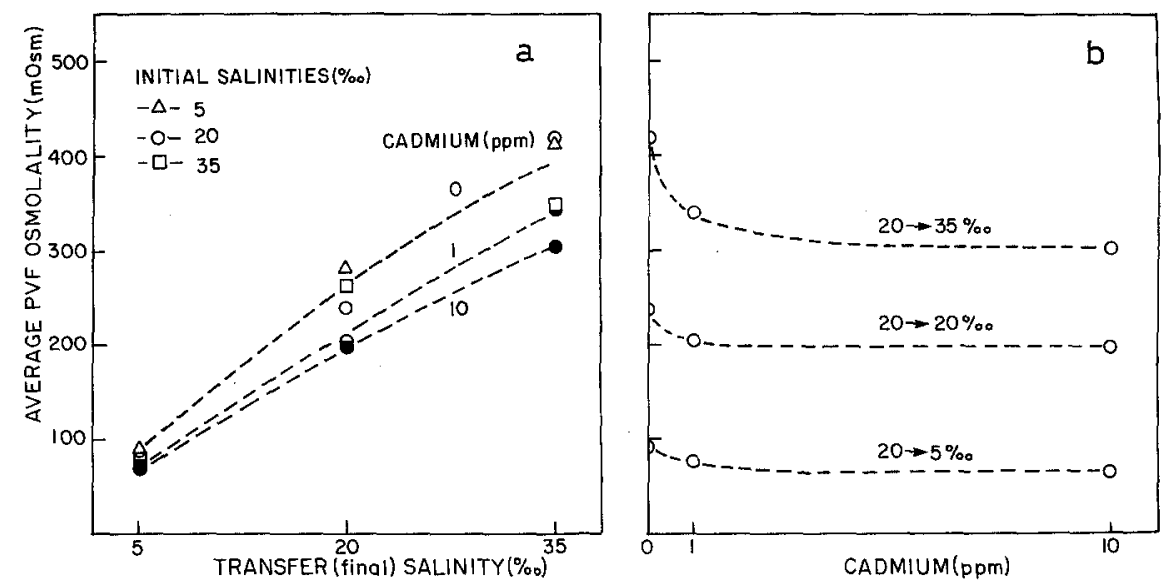

Fig. 5: Influence of cadmium $(0,1,10 \mathrm{ppm})$ on the average perivitelline fluid osmolality throughout incubation (see Table 5) in relation to (a) final salinity after egg transfer, and (b) cadmium concentration. Panel a indicates the salinities from which the eggs were transfered. Symbols: open, 0 ppm; semi-closed, 1 ppm; closed, 10 ppm Cd

It was not possible to obtain companion yolk samples at each sampling period; those obtained are listed in Table 8 . There are no obvious trends in the available data, and no conclusions can be drawn regarding the possible influence of cadmium on yolk osmoconcentration.

The influence of cadmium on osmolality of the eggs is summarized in Fig. 6, where PVF and yolk osmoconcentration of cadmium-exposed eggs is compared with that for eggs in the previous series where cadmium was absent. Both PVF and yolk osmolalities are 
Osmotic responses

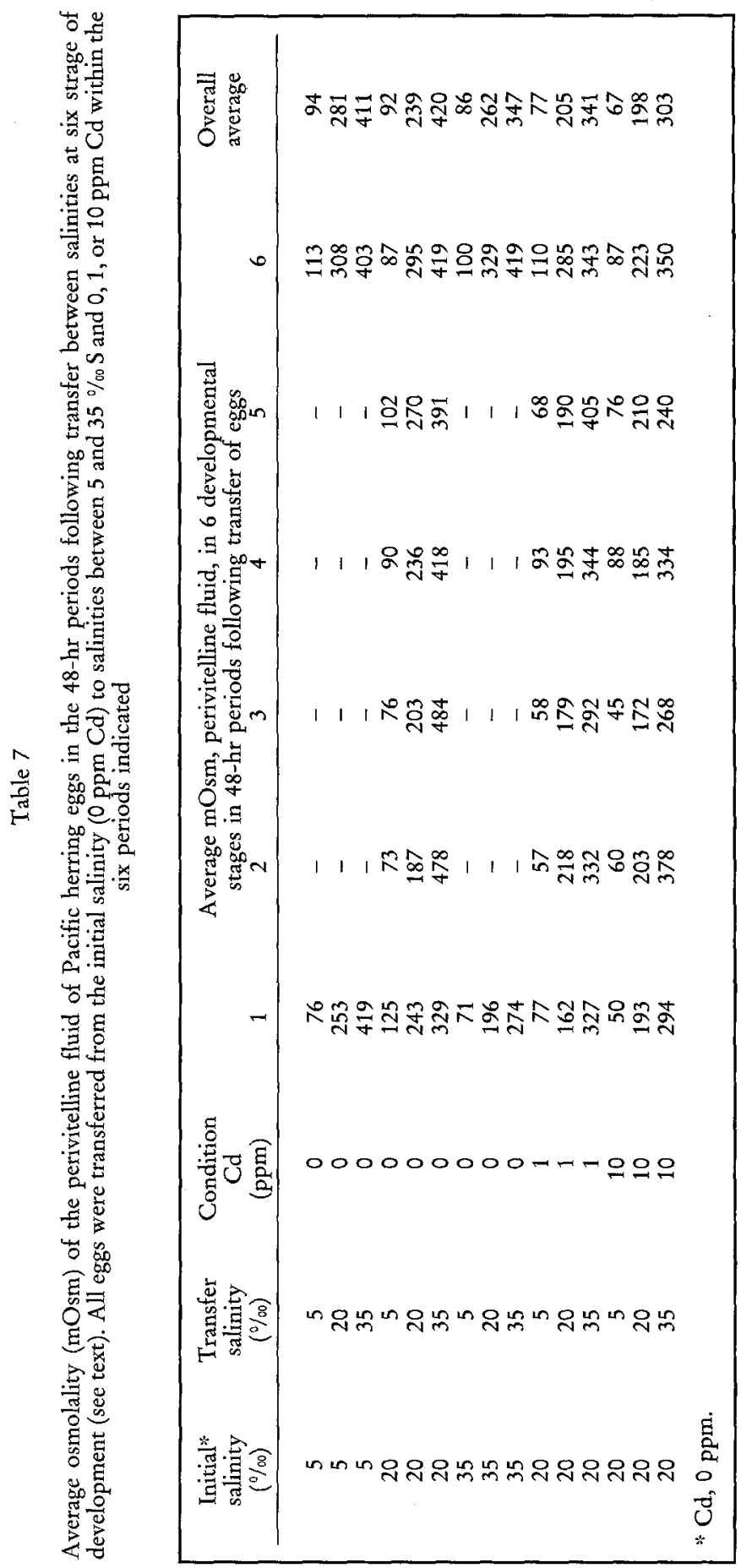




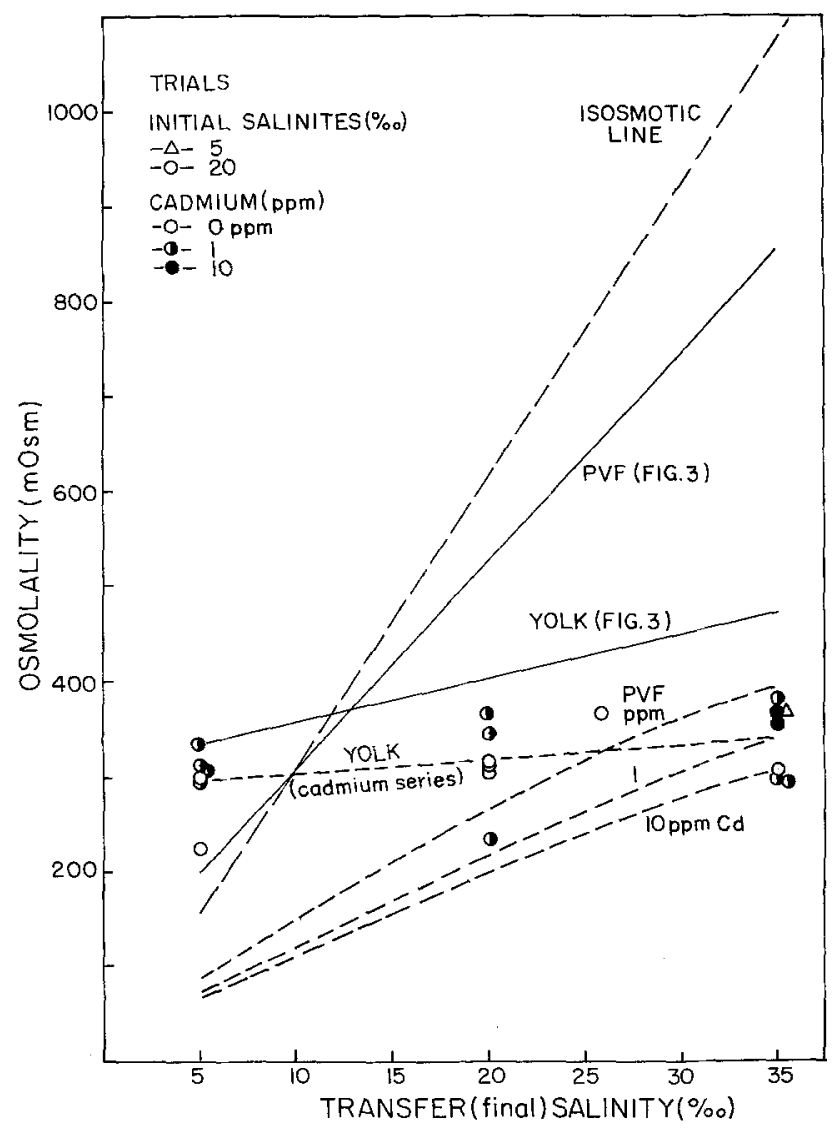

Fig. 6: Overlay of the trend lines from Fig. 3 and 5a demonstrating the yolk and PVF osmolalities of eggs in the cadmium series compared with those obtained in the initial osmoconcentration series (no cadmium). The trend for yolk osmolality in the cadmium series is drawn through the average osmolality for the clusters of points shown. The points are listed in Table 8 . (For the symbols, see Fig. 5)

lower in the controls for the cadmium-exposed eggs than in eggs from the previous series (Fig. 3). The possible effect of cadmium on yolk osmoconcentration cannot be ascertained from the available data. However, cadmium reduces PVF osmolality, and the reduction is greater at higher cadmium concentrations and in higher salinities.

\section{Salinity tolerance of larvae}

Total mortalities occurring in each salinity trial in the 72-hr test period for larvae at the four ages examined are shown in Fig. 7. In general, mortality at each age decreased from maxima at the salinity extremes to minima near 5 and $20 \% \mathrm{~S}$. The distributions of mortality associated with lower and higher salinities (Fig. 7) were rescaled using the arcsin transform $(\varphi=2 \arcsin \sqrt{\mathrm{x}} ; \mathrm{x}=\mathrm{y} / \mathrm{n}$, the proportion responding) and the salinities 


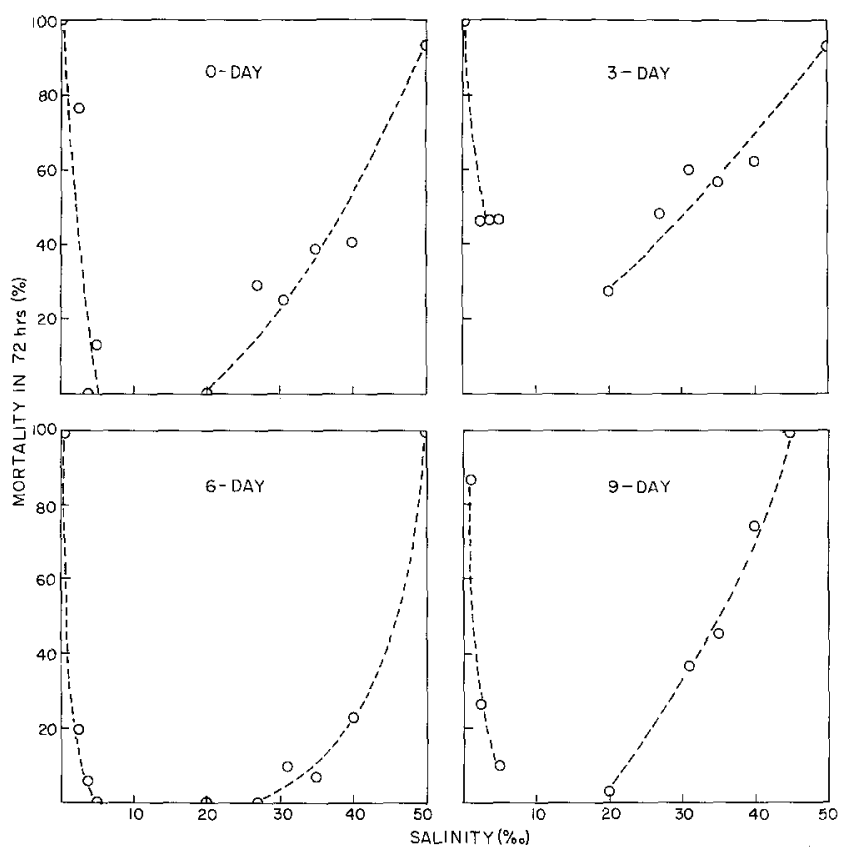

Fig. 7: Percentage mortality in samples of 15 Pacific herring larvae taken from $20 \% \mathrm{~S}\left(8.5^{\circ} \mathrm{C}\right)$ and exposed to various salinities from 0 to $50 \%\left(8,5^{\circ} \mathrm{C}\right)$ for $72 \mathrm{hr}$. The points show total mortality resulting from the $72-\mathrm{hr}$ exposure. The test series were repeated on groups of larvae on the day of hatching, and 3, 6, and 9 days after hatching

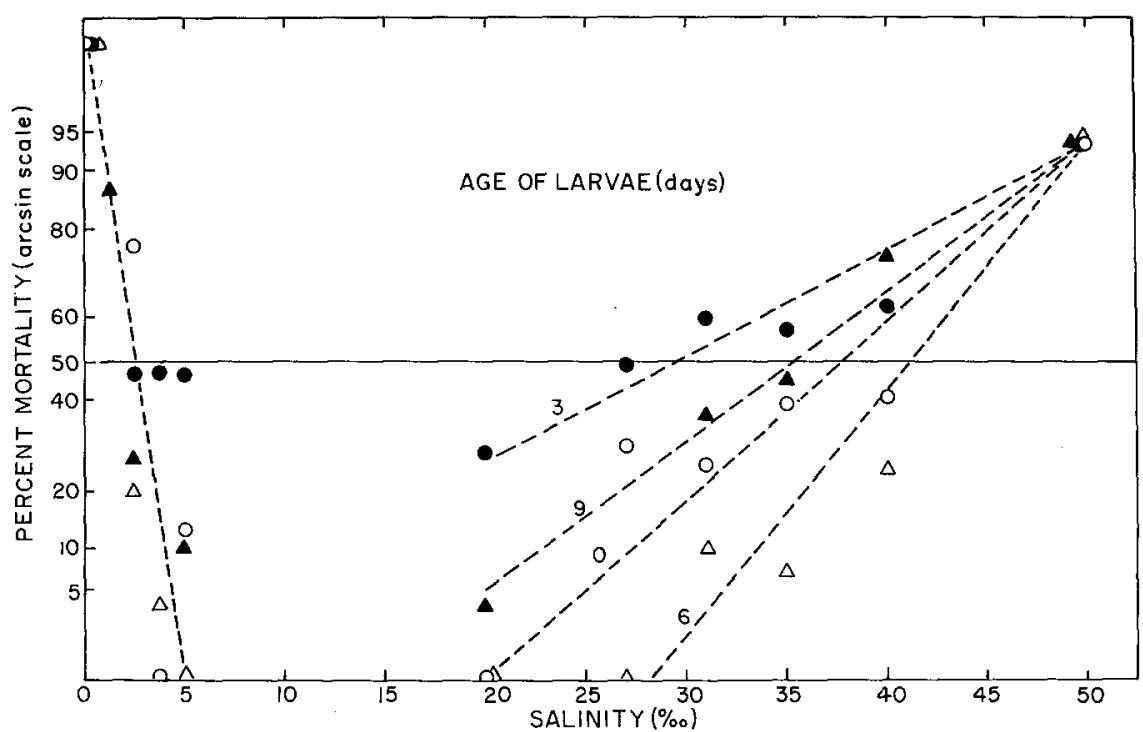

Fig. 8: Percent mortality (arcsin scale) for the data of Fig. 7. Substantial (28\%) mortality occurred in the series for 3-day old larvae at $20 \% \mathrm{~S}$ and this distribution was adjusted (in the text) for mortality in the controls. The low salinity associated with $50 \%$ mortality (72 hr) averages approximately $2.75 \%$ $\mathrm{S}$; that for the high salinity averages $35.8 \% \mathrm{~S}$ 
Table 8

Individual measurements of yolk osmolality (mOsm) of Pacific herring eggs in 48-hr periods following egg transfer between salinities at various developmental stages. All transfers were from the initial salinity $(0 \mathrm{ppm} \mathrm{Cd})$ to salinities of 5,20 or $35 \%$ within the developmental periods indicated (brackets)

\begin{tabular}{|c|c|c|c|c|}
\hline \multirow{2}{*}{$\begin{array}{l}\text { Cadmium in } \\
\text { final salinity } \\
\text { (ppm) }\end{array}$} & \multicolumn{4}{|c|}{$\begin{array}{l}\text { Yolk osmolality (mOsm) } \\
\text { following salinity transfer }\end{array}$} \\
\hline & $20 \rightarrow 5 \%$ & $20 \rightarrow 20 \%$ & $20 \rightarrow 35 \%$ & $5 \rightarrow 35 \%$ \\
\hline \multirow[t]{3}{*}{0} & $298(3)$ & $317(3)$ & $308(5)$ & $368(1)$ \\
\hline & - & $314(4)$ & - & - \\
\hline & - & $306(4)$ & - & - \\
\hline \multirow[t]{4}{*}{1} & 335 (1) & 235 (1) & $298(1)$ & - \\
\hline & $313(4)$ & $346(1)$ & $383(4)$ & - \\
\hline & 307 (4) & $366(5)$ & $295(4)$ & - \\
\hline & $295(5)$ & - & - & - \\
\hline \multirow[t]{2}{*}{10} & $224(1)$ & - & $368(2)$ & - \\
\hline & - & - & $335(5)$ & - \\
\hline
\end{tabular}

corresponding to $50 \%$ mortality in the 72 -hr test period were estimated from the resulting graph (Fig. 8). The distribution of estimates of mortality for 3-day old larvae in salinities of $20 \%$ or more (Fig. 7) seems anomalous. About $28 \%$ mortality occurred in the $20 \% \mathrm{~S}$ test in the 72 -hr period. The decision was made to retain the $20 \% \mathrm{~S}$ test as a control. Therefore a correction was made to the estimates of mortality in the 3-day larval series, using Abbott's formula (Finney, 1952) for mortality in the controls. The correction moved the estimate of the $72-\mathrm{hr} \mathrm{TL}$ from about 29 to $36.5 \% \mathrm{~S}$. With this adjustment, the $72-\mathrm{hr}$ $\mathrm{TL}_{\mathrm{m}}$ estimates (Table 9) for the four ages of larvae were obtained graphically:

Table 9

Median tolerance limits $(72 \mathrm{~h})$ of Clupea pallasi larvae for different salinities in relation to age of larvae

\begin{tabular}{|c|c|c|}
\hline \multirow{2}{*}{$\begin{array}{l}\text { Age of larvae } \\
\text { (days) }\end{array}$} & \multicolumn{2}{|c|}{ 72-hr TLm $(\% \mathrm{~S})$} \\
\hline & lower & upper \\
\hline 0 & 2.5 & 35.5 \\
\hline 3 & 3.0 & 36.5 \\
\hline 6 & 2.5 & 42.5 \\
\hline 9 & 3.0 & 35.5 \\
\hline
\end{tabular}

The data are too limited to suggest trends. Averaging the estimates, $50 \%$ mortality is estimated to occur in samples of herring larvae at salinities of 2.75 and $35.8 \%$ over a $72-\mathrm{hr}$ period of exposure.

Probit-response time distributions of the 38 individual tolerance tests of Fig. 7 also were examined. Many of these showed split-probit distributions, particularly at salinities below $5 \%$, suggesting that mortality was the result of more than one causal mechanism. A number of the test distributions also were truncated artifically by stopping the tests 


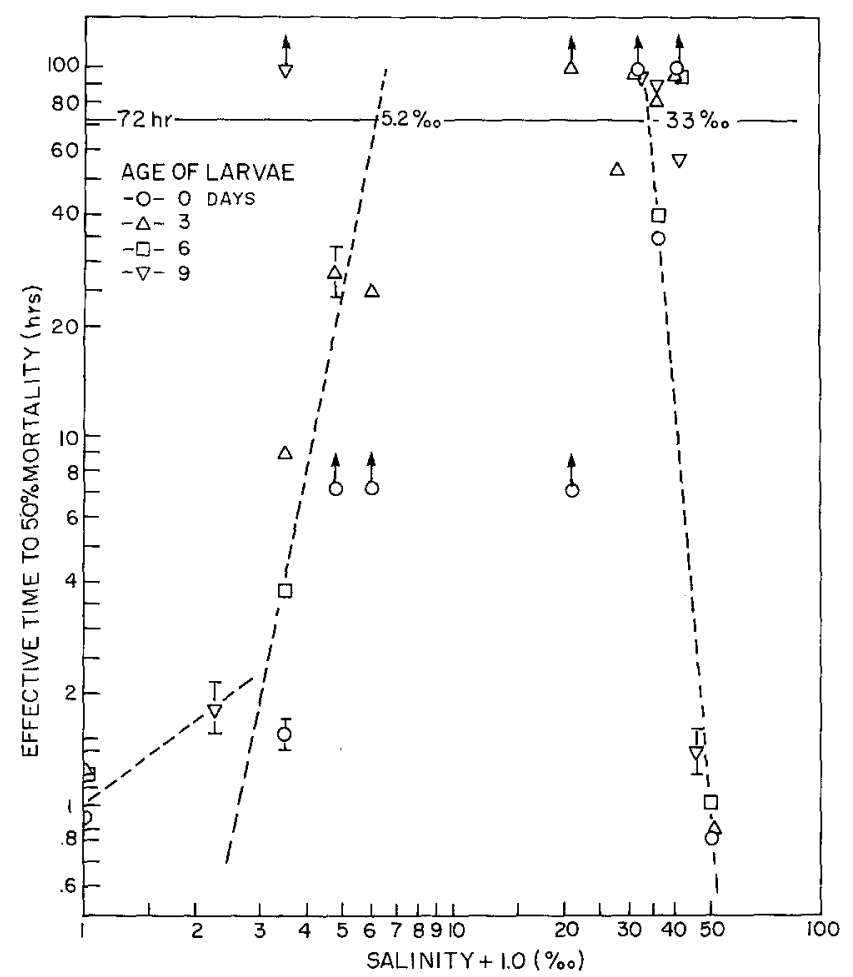

525

Fig. 9: Effective time to $50 \%$ mortality among the individual (38) salinity tolerance tests for the larvae of four ages. The symbols with upward-pointing arrows indicate truncated mortality distributions at the times shown. To accommodate tests at $0 \% \mathrm{~S}$, the value 1 has been added to the scaled salinities; this is subtracted from the estimates at $72 \mathrm{hr}$ to obtain further estimates of salinity tolerance (5.2 and $33 \%$ S) for the pooled tests at four larvel ages

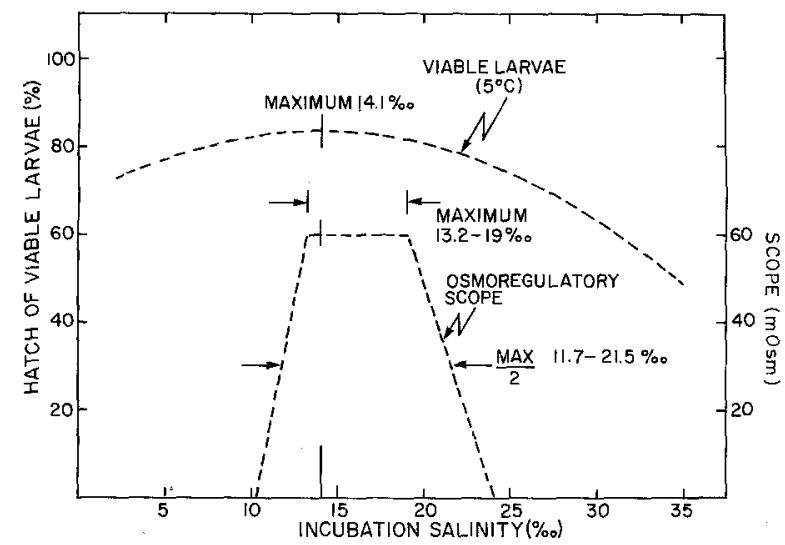

Fig. 10: Suggested relation between osmoregulatory scope and expected hatch of viable larvae. The area for osmoregulatory scope is the difference between the yolk osmolality trend lines (Fig. 3) enclosed within the area of intersection of the yolk and PVF osmolality trends whose points of intersection are isosmotic loci. The trend line for hatch of viable larvae is calculated from the relation given by Alderdice and Velsen (1971); it shows the expected hatch of viable larvae at various incubation salinities for a temperature of $5^{\circ} \mathrm{C}$. Maximum hatch $(83.4 \%)$ at $5^{\circ} \mathrm{C}$ would be expected for an incubation salinity of $14.1 \%$. At $5{ }^{\circ} \mathrm{C}$, maximum osmoregulatory scope is suggested to occur at incubation salinities of 13.2-19\% (scaled from Fig. 3). The area of osmoregulatory scope may shift with temperature (see text) 
arbitrarily at $72 \mathrm{hr}$. A representation of those tests for which the effective time to $50 \%$ mortality fell within or near the boundaries of the 72-hr test period (Fig. 9) provides a second estimate of 72 -hr median tolerance limits for salinity. Estimated from the figure, these limits are 5.2 and $33 \% \mathrm{~S}$. Nevertheless, the mortality distributions of Fig. 7 suggest that appreciable mortality could occur in natural populations of herring larvae at intermediate salinities between 20 and $33 \%$ at a temperature of $8.5^{\circ} \mathrm{C}$.

In summary, estimates of salinity tolerance of 0 - to 9-day old Pacific herring larvae (72-hr $\mathrm{TL}_{\mathrm{m}}$ ) range from $2.8-5.2$ to $33-35.8 \% \mathrm{~S}$. Minimum salinity-related mortality probably occurs within the range of 5 to $20 \%$ S. Substantial salinity-related mortality could be expected at salinities between 20 and $33 \%$.

\section{DISCUSSION}

\section{Osmotic properties of eggs}

There are three sources of variation that initially may have influenced the osmoconcentration of the eggs used in the five series (Table 3). These are (1) the prespawning salinity experience of the adults from which the gametes were obtained, (2) storage of eggs at $4{ }^{\circ} \mathrm{C}$ in $20 \% \mathrm{~S}$ sea water for about $1 \mathrm{hr}$ prior to fertilization, and (3) the fact that a small amount of perivitelline fluid would have been formed in the $10-\mathrm{min}$ period of fertilization in $20 \% \mathrm{~S}$ before the eggs were moved to their incubation salinities.

In general, ovarian eggs prior to spawning appear to be isosmotic or slightly hypoosmotic in relation to the blood serum of the parent fish (Holliday \& Blaxter, 1960; Holliday, 1965; Holliday \& Jones, 1965, 1967; Holliday, 1969). Furthermore, Solemdal (1967) has shown that serum osmolarity of the flounder (Pleuronectes flesus) is related to that of its environment, and adjusts with transfer of fish from one salinity to another. Changes in buoyancy of eggs from such adults also indicate that osmotic adjustments of ovarian eggs occur in relation to changes in serum osmoconcentration. The adult herring used in this study probably were exposed to salinities of 30-32\% at and prior to capture; they were held at a salinity of $28 \%$ thereafter. We have no information on the serum osmoconcentration of the adult herring used. However, eight determinations of yolk osmolality were made within 12-15 min of fertilization and these averaged $342 \mathrm{mOsm}$, equivalent to a salinity of $11.1 \%$. By comparison, yolk osmoconcentration in Atlantic herring eggs is equivalent to $12.5 \% \mathrm{~S}(\Delta=0.75)$, the corresponding adult serum osmoconcentration being equivalent to $15.3 \% \mathrm{~S}(\triangle=0.92)$ (Holliday, 1965). We assume that the salinity equivalent of adult Pacific herring serum may be several parts per mille higher than $11.1 \%$.

We have no data on the possible influence on yolk osmolality of the salinity in which the eggs were stored, prior to fertilization. Permeability of the vitelline membrane enclosing the yolk is relatively high in Salmo salar prior to fertilization; after fertilization, permeability of the membrane is reduced markedly by the time of first cell division (Loeffler \& Løvtrup, 1970). It is noted that the estimate of yolk osmolality obtained within minutes of fertilization ( $342 \mathrm{mOsm})$ is very similar to that established in the period of relative stability $(100-250 \mathrm{hr})$ in eggs incubated in $20 \%$ sea water $(350 \mathrm{mOsm})$. This 
would agree with results of Holliday \& Jones (1965), who found that the yolk of unfertilized eggs of Atlantic herring conformed closely to the salinity of the medium in which they were placed after an exposure period of $1 \mathrm{hr}$.

Alderdice et al. (1979b) found that perivitelline fluid formation in Pacific herring eggs $\left(20 \% \mathrm{~S}, 5^{\circ} \mathrm{C}\right)$ was observable 7 min after fertilization and that maximum egg volume following imbition was achieved in $6-9 \mathrm{hr}$ in $20 \% \mathrm{~S}$ at $5{ }^{\circ} \mathrm{C}$. An estimated $11-12 \%$ of the increase in total volume would occur within a 10-min period following fertilization, the period the eggs would be in the $20 \%$ fertilization salinity. Formation of the perivitelline fluid probably occurs during the time in which permeability of the vitelline membrane is high (Potts \& Rudy, 1969; Loeffler \& Lovtrup, 1970). Holliday \& Blaxter (1960) found that Atlantic herring eggs fertilized in a higher salinity $(32.3 \%)$ and incubated in a lower salinity $(10.9 \%$ ) had a slightly higher PVF osmoconcentration, 7-8 days after fertilization, than eggs fertilized and incubated in $10.9 \% \mathrm{~S}$. Holliday \& Jones (1965) compared yolk osmoconcentrations in yolk of Atlantic herring eggs (a) fertilized and incubated in four salinities $(5,17.5,35,50 \%)$, and (b) fertilized in $35 \% \mathrm{~S}$ sea water and moved to the same four salinities after $30 \mathrm{~min}$. In general, osmoconcentration followed the same trends in each series. Thus we suspect that salinities of storage and fertilization can have small transitory effects on yolk and PVF osmolality, effects that may have a minor influence on subsequent events after the completion of imbibition and water hardening.

Following movement of the eggs from the fertilization medium $(20 \% \mathrm{~S})$ to the incubation media $(5,20,35 \% \mathrm{~S})$, changes in osmoconcentration of both the yolk and perivitelline fluid were substantial within the first $100 \mathrm{hr}$ of incubation (Fig. 1). When the eggs had developed to the stage where the germ ring had advanced to the equator of the yolk, transfer of eggs between salinities of 5 and $35 \%$ was followed immediately by rapid adjustments of yolk and perivitelline fluid osmoconcentration. The greater part of these changes occurred within 2-3 hr of transfer, but residual changes continued for a period of about $48 \mathrm{hr}$.

Holliday (1969) suggests that in general the embryonic tissues are in direct contact with a perivitelline fluid very similar to the medium in which the eggs are incubated. As a very rough approximaton this is true in the current series (Fig. 1). Holliday \& Jones (1965) also conclude that osmoconcentration of the yolk is indicative of embryonic tissue osmolality. Events within the first $100 \mathrm{hr}$ of incubation in this study suggest there is a transition between osmoconformation and osmoregulation between 60 and $85 \mathrm{hr}$ after fertilization. For example, prior to $60 \mathrm{hr}$ there appears to be a slow decrease in yolk osmolality in the eggs maintained in $5 \% \mathrm{~S}$ sea water (Fig. 1a). Osmoconcentration of the yolk tends toward an equilibrium with the external medium, the rate of change presumably being controlled by the low permeability of the vitelline membrane. Between 60 and $85 \mathrm{hr}$ this trend is halted and by $100 \mathrm{hr}$ regulation of osmoconcentration appears to be established. In this regard Pacific herring eggs respond in a manner very like that found by Holliday \& Jones (1965) for Atlantic herring eggs. However, osmotic regulation is necessarily restricted to tissues developing during and following epiboly. In Pleuronectes platessa (Holliday \& Jones, 1967), regulation seems to be achieved shortly after fertilization.

The period of relative stability in yolk and perivitelline fluid osmolality (100-250 hr) conforms with the conclusions of Holliday \& Jones (1965) that regulation in the Atlantic 
herring egg begins with blastodermal overgrowth and is achieved at the time of blastopore closure. The period of stability of osmoconcentration of the Pacific herring egg corresponds with a similar period of relative stability of total egg volume (Alderdice et al., 1979b). The slow rise in yolk and PVF osmolality from $250 \mathrm{hr}$ until hatching suggests there may be a slow loss of yolk water during later development; some PVF samples obtained from eggs in 5 and $20 \% \mathrm{~S}$ just prior to hatching were notably viscous. Changes in the perivitelline fluid also could occur if products of metabolism, too large to pass through the capsule, were being accumulated in the perivitelline fluid.

The question of how the Pacific herring egg achieves its euryplastic response to salinity during incubation is one of continuing interest. To explore this question, some assumptions are made based on the current findings and from earlier data. Attention is drawn to the quadrilateral figure formed by intersection of the yolk and PVF osmoconcentration lines for the period of relative stability and for the prehatching period (Fig. 3). Some associated incubation salinities and yolk and PVF osmolalities estimated from the figure are listed in Table 10. Some of the associations noted are those where either the yolk or the perivitelline fluid are isosmotic with respect to each other or with reference to the incubation salinity. With the exception of the 2.2 and $9.7 \%$ isosmotic associations, the associations define the boundaries of the quadrilateral figure (Fig. 3). We assume that these isosmotic associations define a zone of osmotic experience leading to minimum osmotic work and therefore maximum scope for osmoregulation. We assume further that survival of eggs to hatching should be maximized within the zone of maximum osmoregulatory scope. To test this assumption, a survival curve for percentage hatch of viable Pacific herring larvae may be constructed from earlier data (Alderdice \& Velsen, 1971; p. 1551) cver a range of salinities at $5{ }^{\circ} \mathrm{C}$. On this curve, maximum hatch of viable larvae at $5{ }^{\circ} \mathrm{C}$ would be expected at a salinity of $14.1 \%$. The "osmoregulatory scope" curve is constructed on the basis of the scope in milliosmoles expected at salinities within the intersection area in Fig. 3. This curve and that for expected percentage hatch of viable larvae are compared in Fig. 10. From the figure: (1) maximum percentage hatch of viable larvae is assumed from the model to occur within the range of salinities providing maximum osmoregulatory scope (about 13.2-19\%); (2) from previous data, near-maximum percentage hatch of viable larvae $(>80 \%)$ would be expected within a range of 7.5-21\% $\mathrm{S}$; and (3) viable hatches $>80 \%$ are associated with at least one-half maximum scope, within a range of salinities of about $11.7-21.5 \%$. Of interest also is the fact that calculated ultimate maximum hatch of viable larvae in terms of both salinity and temperature would be expected at about $17 \%$ S and $8.3^{\circ} \mathrm{C}$ (Alderdice \&Velsen, 1971). By similar calculation, maximum hatch of viable larvae at the supraoptimal temperature of $10^{\circ} \mathrm{C}$ would be expected at a salinity of about $18.4 \%$, a salinity near the upper boundary of the range estimated for maximum osmoregulatory scope. A temperature of $10^{\circ} \mathrm{C}$ appears to be near the upper limit for spawning of natural populations of Pacific herring (Alderdice \& Velsen, 1971). In addition, at a temperature of $4.0^{\circ} \mathrm{C}$, which is near the lower lethal temperature for development of Pacific herring eggs in British Columbia waters (Alderdice \& Velsen, 1971), the salinity for maximum hatch of viable larvae is about $13.2 \%$. This salinity is near the lower limit of the range for maximum osmoregulatory scope. All of these suggested relations reinforce the earlier observation that there is a low $/$ low-high/high interaction between salinity and temperature in relation to development of Pacific herring 
Osmotic responses

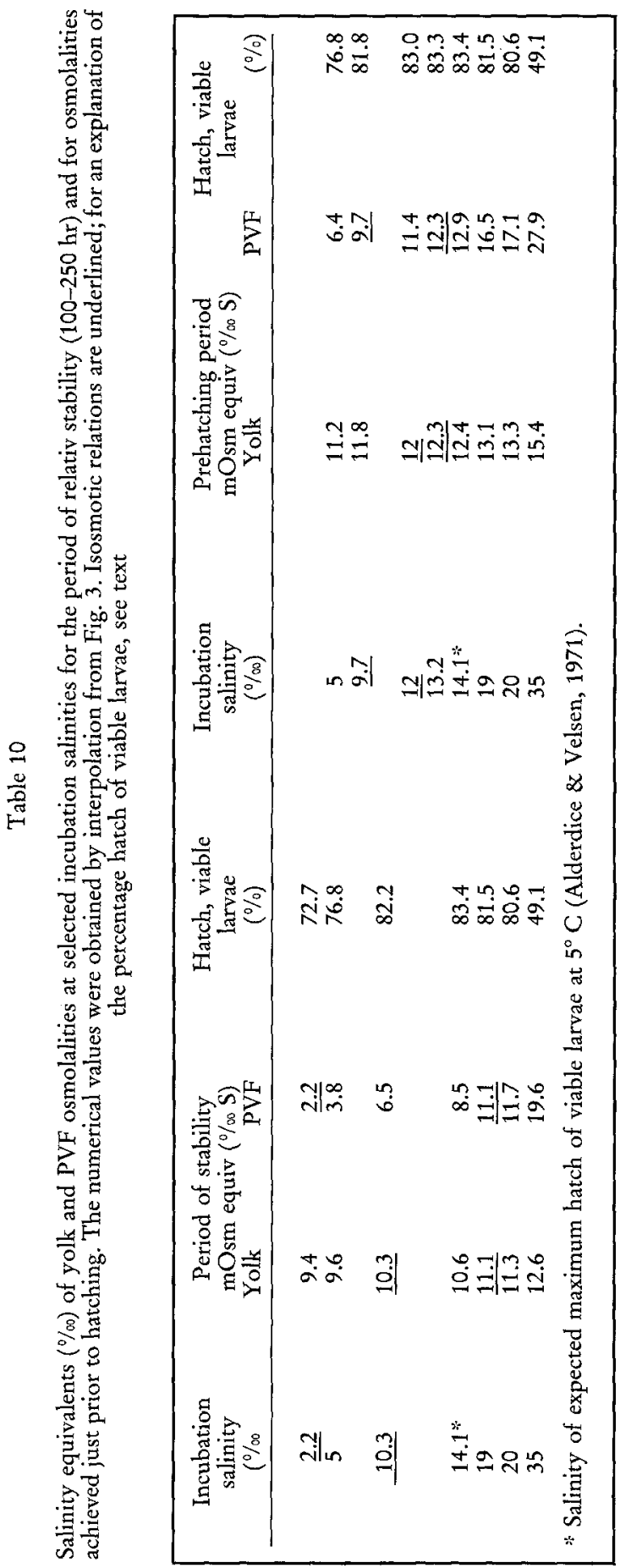


eggs. Therefore, it appears that the range of salinities associated with maximum osmoregulatory scope provides for maximum or near-maximum hatches of viable larvae in relation to the range of temperatures associated with natural incubation. These relations are summarized in Table 11.

Table 11

Clupea pallasi embryos. Range of salinity - temperature conditions for maximum viable hatch as related to salinities of maximum osmoregulatory scope

\begin{tabular}{|ccc|}
$\begin{array}{c}\text { Incubation } \\
\text { temperature }\left({ }^{\circ} \mathrm{C}\right)\end{array}$ & $\begin{array}{c}\text { Max. hatch } \\
\text { viable larvae }\end{array}$ & $\begin{array}{c}\text { Salinity }(\% / \%) \\
\text { Approx. salinity of max. } \\
\text { osmoregulatory scope }\end{array}$ \\
\hline $4.0(\mathrm{~min})$ & 13.2 & 13.2 \\
$8.3(\mathrm{opt})$ & 17 & 17.2 \\
$10(\mathrm{max})$ & 18.4 & 19 \\
\hline
\end{tabular}

These combinations would appear to define the approximate range of salinity-temperature conditions for normal development of Pacific herring eggs.

In the foregoing the numerical values given are first estimates, based on limited data. The associations between incubation salinity and yolk and PVF osmolality (Fig. 3) are assumed to be linear; more complete data could modify this assumption and alter the boundaries of the scope for osmoregulation as portrayed. The survival curve of Fig. 10 also is a best estimate, based on available data. In summary, based on the current evidence we conclude that Pacific herring eggs have the greatest chance of developing into normal larvae at salinities minimizing osmotic work, which are assumed to maximize the scope for osmotic regulation. Estimated for incubations at $5^{\circ} \mathrm{C}$, these salinities range from about 13.2 to $19 \%$ and are associated by a low/low-high/high interaction with temperatures ranging, respectively, from about 4.0 to $10^{\circ} \mathrm{C}$.

The question of whether or not the osmoregulatory scope as defined would differ at other incubation temperatures is of considerable interest. We have no data, other than that at $5^{\circ} \mathrm{C}$, with which to examine this question further. It is conceivable that yolk and PVF osmolalities could describe different trends, and isosmotic relations, at other temperatures. We suggest that the area of intersection associated with osmoregulatory scope continues above and below the plane of the paper in Fig. 10 at other temperatures. Perhaps the range of salinities associated with maximum osmoregulatory scope shifts to higher salinities at higher incubation temperatures. We suspect that ultimate maximum osmoregulatory scope would be found at an incubation near $16.98 \% \mathrm{~S}$ and $8.3^{\circ} \mathrm{C}$, the combination calculated earlier (Alderdice \& Velsen, 1971) to optimize hatch of viable larvae with respect to both salinity and temperature. A shift of the salinity range associated with maximum osmoregulatory scope - to higher salinities (to the right, Fig. 10) and temperatures - could be the compensatory mechanism providing the euryplasticity by which maximum (but suboptimum) hatches of viable larvae would be attained at supraoptimal temperatures above $8.3^{\circ} \mathrm{C}$. The opposite would be expected at suboptimal incubation temperatures below $8.3^{\circ} \mathrm{C}$, maximum osmoregulatory scope shifting to lower salinities and associated temperatures, including the $5^{\circ} \mathrm{C}$ example described by the current data. 
Based on the paradigm outlined, the osmoregulatory behaviour of Pacific herring eggs may be compared with that of Atlantic herring eggs using the data of Holliday \& Jones (1965) (their Figs 3, 4). A major difference in osmoregulatory behaviour of the eggs of the two species is suggested by the comparison. Yolk osmoconcentration of Pacific herring eggs in the period of stability, and prior to hatching, achieve levels proportional to the salinity of incubation. In contrast, eggs of Atlantic herring show an increase or decrease of yolk osmoconcentration, respectively, in high or low incubation salinities. After about 100 $\mathrm{hr}$, yolk osmoconcentrations of Atlantic herring eggs in salinities of 5 to $50 \%$ begin to converge, reaching final prehatching values around a $\Delta$ of $1.1^{\circ} \mathrm{C}$ - equivalent to a salinity near $17.5 \%$. If these data are analyzed in the manner employed in Fig. 3, then prehatching yolk osmoconcentrations are found to parallel those for Pacific herring eggs at salinities of 5 to $35 \%$ but at a level about $150 \mathrm{mOsm}$ higher at each incubation salinity. In addition, yolk osmoconcentrations estimated for the period following $100 \mathrm{hr}$ - approximating the period of stability of Pacific herring eggs - are lower than prehatching levels at lower incubation salinities $(5,17.5 \%)$ and higher at higher salinities $(35,50 \%)$. That is, the two trends of yolk osmoconcentration intersect at an incubation salinity of 20-21\% where the minimum difference between early and prehatching yolk osmoconcentrations would be found at the equivalent of $17.5 \% \mathrm{~S}$ for the yolk. Although the data are insufficient to allow further comparison, the patterns of osmoregulatory behaviour appear basically dissimilar. However, the point of intersection mentioned suggests that Atlantic herring eggs incubating in a salinity near 20-21\% would be subject to least osmotic work. Also, it should be noted that Holliday \& Jones (1965) worked mostly at a temperature of $7^{\circ} \mathrm{C}$. Our estimates of incubation salinities resulting in minimum osmotic work at $7^{\circ} \mathrm{C}$ would be (1) about $16 \%$ for Pacific herring eggs (scaled from the previous text table), and (2) 20-21\% for Atlantic herring eggs. We conclude, tentatively, that Atlantic herring eggs are more tolerant of higher incubation salinities than Pacific herring eggs, by virtue of their ability to sustain higher internal osmotic concentrations during embryonic development.

The foregoing conclusion is supported by a further comparison of the effect of the salinity of incubation on survival to hatching. A percentage hatch of $30-40 \%$ would be expected among Atlantic herring eggs incubated at $50 \% \mathrm{~S}$ (Holliday \& Blaxter, 1960; Holliday, 1965). The expected hatching rate of Pacific herring eggs incubated at $50 \% \mathrm{~S}$ would be less than $5 \%$ (Alderdice \& Velsen, 1971). The estimates of survival to hatching obtained in the current series approximate those expected in constant salinity incubations at $5{ }^{\circ} \mathrm{C}$ (Alderdice \& Velsen, 1971). These are: $5 \%-76.8 \% ; 20 \%-80.7 \%$; and $35 \%$ - $49.1 \%$ (cf. Table 4). However, those eggs moved from 5 to $35 \% \mathrm{~S}$ produced fewer viable larvae $(22.8 \%$ ) than were obtained from eggs maintained in $35 \% \mathrm{~S}(49.3 \%)$. In general, the comparison supports the contention that Pacific herring eggs are less tolerant of higher salinities than Atlantic herring eggs.

In summary, it appears that the euryhalinity of Pacific herring eggs is a result of the interaction of salinity and temperature on osmoregulatory behaviour. We suspect that the mechanism involved operates by minimizing osmotic work at particular salinities, the latter being defined by associated levels of temperature. We note that salinities calculated to maximize hatch of viable larvae from Pacific herring eggs (13-19\% S; Alderdice \& Velsen, 1971) correspond closely with those that maximize hatch of viable larvae at limiting temperatures for egg development and natural spawning (13.2-18.4\%) and with those 
temperature-associated salinities that maximize osmoregulatory scope $(13.2-19 \%)$. In comparison, Holliday \& Blaxter (1960) concluded that the optimum salinity range for Atlantic herring egg development is approximately 20-35\%. We note that an incubation salinity of 20-21\% probably is related to minimum osmotic work in Atlantic herring eggs and suspect that their osmoregulatory behaviour with respect to incubation salinity probably is modified by an interaction between salinity and temperature similar to that affecting Pacific herring egg development.

\section{Influence of $c$ a d m i m on osmotic properties of egg}

The major change in properties of the egg noted as a result of exposure to cadmium is a decrease in osmolality of the perivitelline fluid (Fig. 4). Osmolality was reduced in higher cadmium concentrations, and the reduction appeared to be accentuated at higher salinities (Fig. 5). Associated changes in osmolality of the yolk were not seen, although relatively few records of yolk osmoconcentration were obtained (Fig. 6).

Also observed were differences in perivitelline fluid osmolality between the controls in the cadmium series ( 0 ppm Cd, Fig. 6) and those in the osmoconcentration series (Figs 3 , 6). As indicated earlier, initial salinity experience differed in these two series. Eggs in both series were fertilized in $20 \% \mathrm{~S}$ sea water. However, those in the cadmium series were moved to their incubation salinities at a time corresponding to about $20 \%$ perivitelline fluid formation, compared with 11-12\% in the first series. Nevertheless, the eggs fertilized and incubated in $20 \% \mathrm{~S}$ sea water in the cadmium series control $(0 \mathrm{ppm} \mathrm{Cd}, \mathrm{Tables} 6,7)$ and in the first series (Table 4), should have similar yolk and PVF osmoconcentrations, but they do not (Fig. 6). Yet, rather similar differences in early salinity exposure were examined by Holliday \& Jones (1965) and were found to have no observable influence on yolk osmoconcentration. In the current study, eggs used in the two series came from the same spawning stock. We know of no reason for the noted difference in osmotic properties of the eggs in the two series, other than the following. The eggs used for the cadmium series were fertilized early in the spawning period (13 March, 1974); those used in the osmoconcentration series were from adults held for a further $3 \frac{1}{2} \mathrm{wk}$ (8 April, 1974). We assume the differences in osmotic properties of the eggs in two series are related to possible variations in ripeness or condition of the eggs during the course of the spawning period or to differences in salinity prehistory.

Effects of exposure of eggs to cadmium during incubation recently have been documented for four marine species: Clupea barengus (Rosenthal \& Sperling, 1974; von Westernhagen et al., 1974), Belone belone (von Westernhagen et al., 1975), Pleuronectes flesus (von Westernhagen \& Dethlefsen, 1975), and Clupea pallasi (Alderdice et al., 1979a, b). From these studies the following generalizations may be made with respect to cadmium: (1) deleterious effects of cadmium are more pronounced at higher concentrations and in lower salinities; (2) embryonic mortality is increased prior to hatching and the percentage hatch of normal larvae is reduced; (3) embryonic activities are reduced, including embryonic fin beats $(B$. belone), embryonic body flexures, and heart rate; (4) total diameter of exposed eggs may be reduced (C. pallasi) or unchanged; (5) fragility of the 
egg envelope (capsule + jelly coat) is increased and the bursting pressure of the egg is reduced; (6) the incubation period may be shortened owing to premature hatching; at hatching, yolk sac size is increased and larval length is decreased; (7) eye diameter and otic capsule diameter are reduced in hatched larvae; in C. pallasi the otic capsules may be missing entirely (Rosenthal and Alderdice, unpublished data).

Comparison of the effects of cadmium exposure (von Westernhagen et al., 1975) amongst the four species suggests that $\mathrm{Cd}^{+2}$ ions compete with and replace $\mathrm{Ca}^{+2}$ at binding sites in the jelly coat and capsule of the egg. Because of the lower $\mathrm{Ca}^{+2}$ content of dilute sea water, it is presumed that $\mathrm{Ca}^{+2} / \mathrm{Cd}^{+2}$ ratios will favour an increase in $\mathrm{Cd}^{+2}$ binding in lower salinities. Rosenthal \& Sperling (1974) noted that about $70 \%$ of the cadmium recovered from Atlantic herring eggs was associated with the egg envelope ("chorion"), the remainder being found in the yolk and embryo. A species comparison also suggests that eggs with thicker jelly coats - such as the demersal eggs of Atlantic and Pacific herring will bind the maximum amount of cadmium during incubation in lower salinities. Nakano (1959) found that "hardening" of the fertilized egg, a process requiring calcium (Kusa, 1949 ) is inhibited by cadmium; Zotin (1958) showed that hardening of the egg involves a change in properties of the capsule. A question remains as to whether cadmium influences the properties of the capsule, the jelly coat, or both. It is noted that weakening of the capsule occurs in the presence of cadmium in eggs of Pleuronectes flesus (von Westernhagen \& Dethlefsen, 1975), a species in which the jelly coat of the egg is either very thin or absent. Alderdice et al. (1979a) also found that the rate of attainment and level of bursting pressures achieved were altered in cadmium-exposed Pacific herring eggs. They concluded that alterations in the properties of both the jelly coat and capsule contributed to the observed changes in bursting pressure characteristics.

Many of the observed effects of cadmium exposure outlined - including delayed attainment of maximum bursting pressure, reduced bursting pressure, capsule fragility, and reduction in total volume of the egg - are assumed to be a direct result of changes in physical properties of the capsule and jelly coat resulting from competitive binding of $\mathrm{Cd}^{+2}$ in place of $\mathrm{Ca}^{+2}$. Searching for an explanation of these changes, Alderdice et al. (1979b) suggested that the normal egg acts like a ball with microsieve walls, that water and ions are exchanged across the capsule largely as a result of the osmotic gradient occurring between the perivitelline fluid and the external medium, and that an exchange equilibrium is reached at a limiting circumferential tension imposed on the capsule and jelly through the internal turgor pressure produced by the prevailing osmotic gradient. Such a proposition would seem reasonable if the action of cadmium were one of disrupting the waterhardening process by increasing the "porosity" of the capsule. We assume that for a given osmotic gradient such a system would result in decreased turgor pressure (Eddy, 1974), reduced egg volume, and lower circumferential tension. However the current results, in which cadmium exposure leads to a reduction in perivitelline fluid osmolality, are difficult to rationalize in the model outlined. It is difficult to assume that reduced osmolality could be a result of "leakage" of colloid from the perivitelline fluid through the capsule. It could be inferred that increased capsule porosity would lead to net loss of water from the perivitelline fluid resulting in increased osmolality, which is not so. Furthermore, net decrease in osmolality of the perivitelline fluid resulting from cadmium exposure is lowest in those eggs transferred to low salinities (Fig. 5b); there, one would expect the maximum 
effect of cadmium exposure in dilute sea water. A plausible resolution to this problem is found in the fact that cadmium has a marked tendency to form complexes (Remy, 1956), particularly with iodide, bromide, and chloride ions, all of which are found in sea water. These complex arrangements include autocomplexes and double halide complexes, and a substantial proportion of some forms (e.g. $\mathrm{CdI}_{2}$ ) may exist in solution as undissociated molecules. The effect of formation of these complexes is to marshal other ions into complex formations (e.g. $\mathrm{Cd}\left[\mathrm{CdI}_{3}\right]_{2}$ ), reducing the number of active particles in solution (Remy, 1956). Since osmotic pressure is a function of the number of particles in solution, a process that reduces the total number of particles will reduce the osmotic pressure.

Therefore, we assume that the influence of cadmium on the eggs could be portrayed in the following manner. (1) Cadmium in solution is bound by the jelly coat in relation to the salinity of the external medium, proportionally more cadmium being bound in dilute sea water. This binding alters the properties of the jelly coat, inhibiting its loss of bound water so that the jelly coat hardens more slowly. The contribution of the jelly coat to the bursting pressure of the whole egg is delayed or reduced. (2) In high cadmium concentrations or in high salinities the potential cadmium binding capacity of the jelly coat may be exceeded so that cadmium tends to penetrate the capsule. There it may be bound to the capsule pores on entry or to the interior of the capsule surface after entry. Binding to the capsule alters its structure. Elastic properties of the capsule and its tensile strength are reduced, making it more fragile and subject to rupture. (3) Cadmium entering the egg and the perivitelline fluid forms complex ions and molecules, reducing the number of osmotically active particles in and the osmotic pressure of the perivitelline fluid. (4) Reduced perivitelline fluid osmotic pressure reduces the osmotic gradient with the external medium. Less water is imbibed at equilibrium, tension in the outer envelope is reduced, and the volume of the whole egg is decreased. Obviously, however, much more needs to be learned about cadmium and its effects on properties of the egg in order to test the validity of these assumptions.

Solemdal $(1967 ; 1971)$ has discussed the ecological significance of egg buoyancy in pelagic fish eggs, and its relation to egg size and specific gravity. Based on the current results, exposure of pelagic eggs to cadmium could result in reduced total egg volume and lowered perivitelline fluid osmoconcentration. These changes in cadmium-contaminated eggs could alter their specific gravity and buoyancy, affecting the position of such eggs in the water column in the natural environment and influencing their ability to survive.

\section{Salinity tolerance of larvae}

The preliminary trials and the data illustrated in Fig. 8 suggest that salinity tolerance of Pacific herring larvae might be greatest, as a first approximation, in the range of 5 to $20 \%$ $\mathrm{S}$. The $72-\mathrm{hr}$ median tolerance limits suggest a range of 2.8-5.2 to 33-35.8 \% $\mathrm{S}$. However, based on the four series of trials, expected mortality could be substantial among natural larval populations exposed for longer intervals to salinities near the upper and lower extremities of this range, particularly at salinities between 20 and $33 \%$. McMynn \& Hoar (1953) concluded earlier that salinity tolerance of Pacific herring larvae from the same geographic area ranged between 6.1 and $34.3 \mathrm{~S}$. 
We have no direct evidence on yolk osmolalities associated with salinity tolerance of the larvae. However from the few estimates of yolk osmoconcentration obtained for newly hatched larvae (Table 5), it is seen that yolk osmolality declines at hatching to levels about $50 \mathrm{mOsm}$ below those obtained in embryos prior to hatching (Fig. 3). These larval levels approximate in most instances the yolk osmolalities achieved in the period of stability (100-250 hr) during earlier development. As a basis for comparison, the 72-hr salinity median tolerance estimates of 5.2 and $33 \% \mathrm{~S}$ (Fig. 9) associate with equivalent yolk osmoconcentrations of 9.7 and $12.5 \% \mathrm{~S}$, respectively (interpolated from Fig. 3). Within this yolk osmoconcentration range is a more restricted interval bounded by osmolal equivalents, in the period of stability, of $10.3 \% \mathrm{~S}$ (yolk isosmotic with external medium) and $11.1 \%$ (yolk and perivitelline fluid isosmotic). This more restricted interval was considered the range of yolk osmolalities associated with minimum osmotic work, and was found at incubation salinities ranging from abont 10.3 to $19 \%$ (Table 10). Earlier in the discussion, the potential influence of a salinity-temperature interaction was indicated (Fig. 10), whereby the maximum hatch of viable Pacific herring larvae would be expected from eggs incubated in salinities within the range of 13.2-19\%, depending on the associated temperature. It seems reasonable that a similar low/low-high/high interaction would be of survival value to Pacific herring larvae. Until further data are available, we suggest that maximum salinity tolerance of early Pacific herring larvae is likely to be found in relation to salinities associated with minimum osmotic work (10-19\%), bounded by 72 -hr median tolerance limits of $2.8-5.2$ to $33-35.8 \% \mathrm{~S}$.

In comparison, Atlantic herring larvae regulate their tissue fluids to levels equivalent to salinities of 9.8 to $15.0 \%$ when transferred to a range of salinities, tolerated for $168 \mathrm{hr}$, of 2.5 to $52.5 \%$ (Holliday \& Blaxter, 1960). A linear interpolation of the salinities that these authors found were tolerated for 24 and $168 \mathrm{hr}$ provides an estimate of 1.8 to $57.6 \%$ $\mathrm{S}$ for $72 \mathrm{hr}$. This range may be compared with that obtained for Pacific herring larvae of 2.75-5.2 to 33-35.8 \% S. Comparing the two species, the salinity tolerance trends noted in egg development appear to continue in the early larvae: Atlantic herring larvae are more tolerant of higher salinities than Pacific herring larvae. Although both forms should tolerate similar low salinities, it appears that Pacific herring larvae would be restricted to more dilute coastal waters than their Atlantic counterparts. Furthermore, on the basis of tolerance estimates it would seem that some salinity-induced mortality would occur among larvae in natural waters with salinities greater than $20 \%$. Substantial mortality among early larvae seems possible at salinities of $30 \%$ or more. We assume that Pacific herring larval populations swept into higher salinities by the vagaries of weather and currents could result in appreciable mortality among entrained larvae.

The results of the present and earlier laboratory investigations of British Columbia Pacific herring eggs and early larvae indicate that they are progressively less tolerant of salinities above approximately $20 \%$. Yet in the Strait of Georgia, where the ripe adults were obtained, spawning usually occurs in salinities of 24 to near $29 \%$ and newly hatched larvae are found in similar salinities. Superficially there appears to be a lack of correspondence between laboratory findings and natural observations. In this regard we suspect that a reasonable, though certainly not final, appreciation of the physiological capabilities of eggs and early larvae of Pacific herring has been obtained. What may be missing is an understanding of how those capacities are utilized in the natural environment. How those 
capacities are utilized may be found to depend on the simultaneous operation of other factors of previously unrecognized importance. It has been our experience with other species, and under similar cirumstances, to search in the natural environment for the missing factor or factors rather than to question the validity of the results already obtained. In a number of instance the search has provided the insights required to provide the correspondence sought. From this viewpoint a number of questions are suggested for further enquiry.

(1) The a d u lt s p a w n e r. Little is known of the biology of the spawning adult. What changes occur in the ovarian eggs prior to spawning and in adults spawning at different times throughout the spawning period? Does the condition of the adult influence the response of eggs to environmental conditions during incubtion?

(2) The s p a w n ing e n vir o n m e n t. Many records of "spawning" salinities available to us were obtained in the general areas of earlier spawning and not at the time when spawning occurred. Do the adults make use of area- or time-limited specific salinity-temperature structures? Is the initiation of spawning keyed to weather conditions, tidal cycles, or freshwater inflow (e.g. rainfall) that might influence local conditions at or after spawning? Do in situ fertilization salinities influence hatching success? What salinitytemperature conditions exist on the spawning grounds over the incubation period after spawning?

(3) S a linity tole ran c of la rva e. The salinity-temperature interaction influencing egg development would be advantageous ecologically, if it were to continue in the larval stages. Seasonal increases in water temperature would be coupled with increased salinity tolerance. Are the early larvae more salinity tolerant at higher temperatures? Do they make use of microenvironments, such as the less saline near-surface waters frequently found during the larval period? Some evidence (A. Hourston, personal communication) suggests the do. Salinity tolerance of larval herring must increase with age. When does this occur?

We suspect that systematic investigation of the questions outlined would assist in the resolution of remaining problems regarding salinity tolerance in early life history stages of Pacific herring. In particular we suspect that salinity tolerance in the larvae will be found to depend on an interaction between salinity and temperature. The low/low-high/high interaction suggested should result in maximum survival at salinities that increase progressively in association with the progressively higher temperatures to be expected in the spring larval season.

\section{ZUSAMMENFASSUNG}

Eier des pazifischen Herings wurden mit einem Salzgehalt von $20 \% \mathrm{~S}$ befruchtet und in 5,20 und $35 \% \mathrm{~S}$ bei $5{ }^{\circ} \mathrm{C}$ erbrütet. Etwa $62 \mathrm{~h}$ nach der Befruchtung wurden Eier aus einigen Erbrütungsansätzen von 5 nach $35 \% \mathrm{~S}$ und von 35 nach $5 \%$ überführt. Die Veränderungen der Osmokonzentration der perivitellinen Flüssigkeit und des Dotters wurden in allen Versuchsreihen von der Befruchtung an bis zum Schlupf im 24-h-Intervall verfolgt. In allen fünf Versuchskombinationen war die Osmolalität des Dotters und der perivitellinen Flüssigkeit bis zum Einsetzen der Epibolie sehr variabel. Unmittelbar nach Verschluß des Blastoporus (105-130 h nach der Befruchtung) war in beiden Medien ein 
relativ stabiler Zustand der osmotischen Verhältnisse erreicht, der bis zu einem Alter der Embryonen von $250 \mathrm{~h}$ anhielt. Danach stieg die Osmokonzentration bis zum Schlupf auf ein Maximum asymptotisch an. Das Verhältnis zwischen Salinität und den Osmokonzentrationen des Dotters und der perivitellinen Flüssigkeit zur Zeit der relativen osmotischen Stabilität deutet darauf hin, daß ein Minimum an osmoregulatorischer Arbeit bei einem Salzgehalt von 10.3 bis $11.1 \% \mathrm{~S}$ aufgebracht werden muß, während kurz vor dem Schlupf dieser Wert bei 12-12.3\% S liegt. Für den Dotter liegen die optimalen Osmokonzentrationen, bei denen ein Minimum an osmoregulatorischer Arbeit zu leisten ist, für die beiden entsprechenden Inkubationsabschnitte bei 10.3-19\% S und 12-13.2\% S. In diesem Salzgehaltsbereich werden auch maximale Schlupfraten gesunder, lebensfähiger Larven erzielt. In einer weiteren Versuchsreihe wurden Eier, die in $20 \% \mathrm{~S}$ bei $5{ }^{\circ} \mathrm{C}$ befruchtet waren, auf sechs verschiedenen Entwicklungsstadien in Salzgehalte von 5,20 und $35 \% \mathrm{~S}$ überführt, wobei die Inkubationsmedien gleichzeitig mit Cadmium (Konzentrationen: 0,1 und $10 \mathrm{ppm}$ ) kontaminiert waren. Im Verlauf von $48 \mathrm{~h}$ nach der Uberführung der Eier in diese Inkubationsmedien lag eine deutliche Erniedrigung der Osmolalität in der Periviltellinflüssigkeit vor. Sie stieg mit zunehmendem Salzgehalt und zunehmender Cadmiumkonzentration. In einer weiteren Versuchsreihe wurden geschlïpfte Larven (Alter 0, 3, 6 und 9 Tage) $72 \mathrm{~h}$ lang verschiedenen Salzgehalten zwischen 0 und $50 \% \mathrm{~S}$ ausgesetzt. Die unteren und oberen MTL-Werte (mittlere Toleranzgrenze) lagen bei 2.8-5.2 \% und 33-35.8 \% S. Die Salzgehaltstoleranz war nicht abhängig vom Alter der Larven. Die Osmolalität des Dotters frischgeschlüpfter Larven entspricht der von Embryonen zur Zeit weitgehender osmotischer Stabilität (100-250 h nach der Befruchtung).

Acknoweledgements. The following investigators also contributed to this study and their efforts are gratefully acknowledged: Dr. H. von Westernhagen, Mr. F. P. J. Velsen, Ms. M. Beil. We thank Ms. Bell, in particular for her major assistance to T.R.R. in measurements of osmoconcentration.

\section{LITERATURE CITED}

Alderdice, D. F. \& Velsen, F. P. J., 1971. Some effects of salinity and temperature on early development of Pacific herring (Clupea pallasi). J. Fish. Res. Bd Can. 28, 1545-1562.

- - 1978. Effects of short-term storage of gametes on fertilization of Pacific herring eggs. Helgoländer wiss. Meeresunters. 31, 485-498.

- Rosenthal, H. \& Velsen, F. P. J., 1979a. Influence of salinity and cadmium on capsule strength in Pacific herring eggs. Helgoländer wiss. Meeresunters. 32, 149-162.

$-\ldots$ 1979b. Influence of salinity and cadmium on the volume of Pacific herring eggs. Helgoländer wiss. Meeresunters. 32, 163-178.

Blaxter, J. H. S. \& Holliday, F. G. T., 1963. The behaviour and physiology of herring and other clupeids. Adv. mar. Biol. 1, 261-393.

Dushkina, L. A., 1973. Influence of salinity on eggs, sperm, and larvae of low-vertebral herring reproducing in the coastal waters of the Soviet Union. Mar.Biol. 19, 210-223.

Eddy, F. B., 1974. Osmotic properties of the perivitelline fluid and some properties of the chorion of Atlantic salmon eggs (Salmo salar). J. Zool., Lond. 174, 237-243.

Finney, D. J., 1952. Probit analysis. Cambridge Univ.,London, 318 PP

Frick, J. H., \& Sauer, J. R., 1973. Examination of a biological cryostat/nanoliter osmometer for use in determing the freezing point of insect hemolymph. Ann. ent. Soc. Am. 66, 781-783.

Fujita, T., \& Kokubo, S., 1927. Studies on herring. Bull. Sci. Fish. Hokkaido imp. Univ. 1, 1-127. 
Holliday, F. G. T., 1965. Osmoregulation in marine teleost eggs and larvae. Calif. Coop. Oceanic Fish. Invest. 10, 89-95.

- 1969. The effects of salinity on the eggs and larvae of teleosts.. In: Fish physiology. Ed by W. S. Hoar \& D. J. Randall. Acad. Press, New York, 293-311.

- \& Blaxter, J. H. S., 1960. The effects of salinity on the developing eggs and larvae of the herring. J. mar. biol. Ass. U. K. 39, 591-603.

- \& Jones, M. P., 1965. Osmotic regulation in the embryo of the herring (Clupea harengus). J. mar. biol. Ass. U. K. 45, 305-311.

- - 1967. Some effects of salinity on the developing eggs and larvae of the plaice (Pleuronectes platessa). J. mar. biol. Ass. U. K. 47, 39-48.

Kurata, H., 1959. Preliminary report on the rearing of the herring larvae. Bull. Hokkaido reg. Fish. Res. Lab. 20, 117-138.

Kusa, M., 1949. Further notes on the hardening of the chorion of salmon eggs. Cytologia 15, 145-148.

Loeffler, C. A., \& Løvtrup,S., 1970. Water balance in the salmon egg. J. exp. Biol. 52, 291-298.

McMynn, R. G., \& Hoar, W. S., 1953. Effects of salinity on the development of the Pacific herring. Can. J. Zool. 31, 417-432.

Nakano, E., 1969. Fertilization. In: Comparative morphology, biochemistry, and immunology. Ed. by C. B. Metz \& A. Monroy. Acad. Press, New York, 2, 295-324.

Potts, W. T. W., \& Parry, G., 1964. Osmotic and ionic regulation in animals. Pergamon Press, New York, $423 \mathrm{pp}$.

- \& Rudy, Jr., P. P., 1969. Water balance in the eggs of the Atlantic salmon, Salmo salar. J. exp. Biol. 50, 223-237.

Remy, H., 1956. Treatise on inorganic chemistry. Elsevier, Amsterdam, 2, 1-800.

Rosenthal, H., \& Sperling, K.-R., 1974. Effects of cadmium on development and survival of herring eggs. In: The early live history of fish. Ed. by J. H. S. Blaxter. Springer, Berlin, 383-396.

Solemdal, P., 1967. The effect of salinity on buoyancy, size and development of flounder eggs. Sarsia 29, 431-442.

- 1971. Prespawing flounders transferred to different salinities and the effects on their eggs. Vie Mileu, (Suppl.). 22, 409-423.

Stevenson, J. C., 1962. Distribution and survival of herring larvae (Clupea pallasi Valenciennes) in British Columbia waters. J. Fish. Res. Bd Can. 19, 735-810.

Washburn, E. W., 1928. International critical tables. McGraw-Hill, New York, 4, 1-481.

Weast, R. C. (Ed.), 1969. Handbook of chemistry and physics. The Chemical Rubber Co., Cleveland, Ohio, Getr. Pag.

Westernhagen, H. von \& Dethlefsen, V. 1975. Combined effects of cadmium and salinity on development and survival of flounder eggs. J. mar. biol. Ass. U. K. 55, 945-957.

- - \& Rosenthal, H., 1975. Combined effects of cadmium and salinity on development and survival of garpike eggs. Helgoländer Wiss. Meeresunters. 27, 268-282.

- Rosenthal, H. \& Sperling, K.-R., 1974. Combined effects of cadmium and salinity on development and survival of herring eggs. Helgoländer wiss. Meerésunters. 26, 416-433.

Zotin, A. I., 1958. The menbrane hardening enzyme of salmon eggs. Dokl. Akad. Nauk SSSR 121, $1105-1108$. 